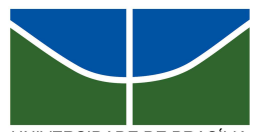

UNIVERSIDADE DE BRASÍLIA

Centro de Excelência em Turismo

Pós-graduação Lato Sensu

Curso de Especialização em Formação de Professores em Turismo

\title{
O POTENCIAL DO TURISMO HISTÓRICO CULTURAL EM JUIZ DE FORA - MG
}

\author{
BRUNA LUÍSA LARCHER GOMES
}




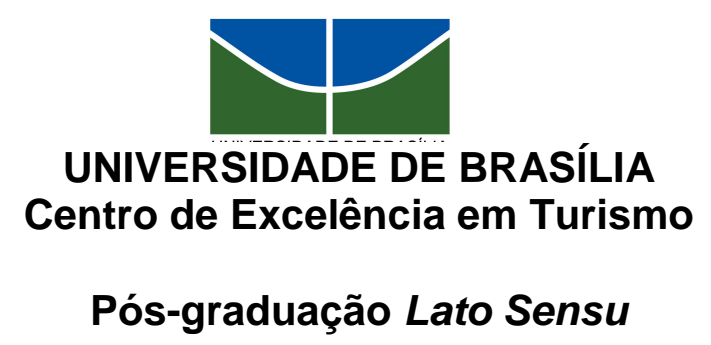

Curso de Especialização em Formação de Professores em Turismo

\section{O POTENCIAL DO TURISMO HISTÓRICO CULTURAL EM JUIZ DE FORA - MG}

\section{BRUNA LUÍSA LARCHER GOMES}

Professor Orientador: Domingos Sávio Spezia, MSc

Monografia apresentada ao Centro de Excelência em Turismo - CET, da Universidade de Brasília - UnB, como requisito parcial à obtenção do grau de Especialista em Turismo. 
UNIVERSIDADE DE BRASÍLIA

Centro de Excelência em Turismo

Pós-graduação Lato Sensu

Curso de Especialização em Formação de Professores em Turismo

\section{Bruna Luísa Larcher Gomes}

Aprovado por:

Prof. Orientador: Domingos Sávio Spezia, MSc

Prof. Avaliador: Gilson Borda,Dr.

Brasília, 1ํ de Julho de 2009. 
Ao meu pequeno Gustavo. 
Meus agradecimentos são em primeiro lugar à minha família que é meu alicerce. Minha Mãe pelo exemplo de superação e pelo incentivo. Ao meu pai por estar sempre comigo. E ao meu amor maior, Gustavo, por encher minha vida de alegria.

Agradeço também as minhas tias Gilda e Gelta por nos acolher durante todo o processo da pesquisa. $\mathrm{E}$ a todos que contribuíram para a realização deste trabalho, com variadas ajudas. Emprestando material, cedendo tempo para realização de entrevistas, disponibilizando informações, e principalmente tomando conta do Gustavo. 
"A educação é aquilo que permanece depois que tudo o que aprendemos foi esquecido." - Burrhus Frederic Skinner 


\section{RESUMO}

No presente estudo é feita uma análise do potencial turístico, histórico e cultural de Juiz de Fora, cidade localizada na zona da mata mineira. Surgida no período da mineração, século XVIII, apresentando, ainda hoje, parte de sua história em algumas construções antigas, museus, teatro, manifestações, e estabelecimentos. Apesar de ser, uma cidade desenvolvida e com infraestrutura de apoio ao turista satisfatória ainda há a necessidade de envolver a comunidade em seu patrimônio histórico cultural fazendo um resgate do mesmo, então este trabalho tem como objetivo gerar alternativas para valorizar suas características histórico culturais. As ferramentas utilizadas para a realização da deste foram: a pesquisa documental a respeito dos possíveis atrativos histórico-culturais, entrevistas a profissionais relacionados às atividades turísticas, à história e à cultura. $\mathrm{O}$ trabalho obteve como resultado a confirmação da existência do potencial histórico-cultural em Juiz de Fora, porém foi possível perceber que este não é utilizado e que não existem projetos satisfatórios para o desenvolvimento sustentável da atividade.

Palavras Chave: Patrimônio histórico cultural, comunidade , Turismo em Juiz de Fora 


\begin{abstract}
The present work analyses the tourist, historical and cultural potential of Juiz de Fora, a city located in the Zona da Mata of the state of Minas Gerais. Juiz de Fora developed during the mining period of the 18 th century and it still presents part of its history in some old buildings, museums, a theatre and other establishments, as well as in some types of public demonstrations. Although it is a developed city, with a satisfactory infrastructure to support the tourist, it still needs to involve its community in their historic and cultural patrimony to retrieve it. This work aims at generating alternative actions to enhance the historical-cultural characteristics of Juiz de Fora. The tools used to achieve this aim were: research into documents related to the potential of historical-cultural attractions, interviews with people engaged in tourist activities as well as in history and culture studies. The results of the work confirmed the existence of a historic-cultural potential to be exploited in Juiz de Fora. It also showed that this potential is not used and that there are no satisfactory projects aiming at promoting a sustainable pursuit of such an activity.
\end{abstract}

Keywords: Patrimony historical-cultural, community, Tourism in Juiz de Fora 


\section{LISTA DE ILUSTRAÇÃO}

Figura 1 Fachada Cine-Theatro Central

Figura 2 Prédio Inicio do Século XX

Figura 3 Praça da Estação

Figura 4 Réplica da Locomotiva

Figura 5 Terceira Capela

Figura 6 Igreja Matriz

Figura 7 Museu Crédito Real

Figura 8 Gráfico:Tempo de permanência do turista em Juiz de Fora

Figura 9 Gráfico: Lugares visitados 


\section{SUMÁRIO}

1 INTRODUÇÃO

1.1 Apresentação e delimitação do tema......................................................12

1.2 Descrição da situação problemática ………….....................................13

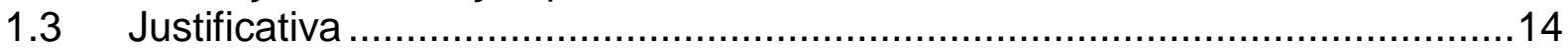

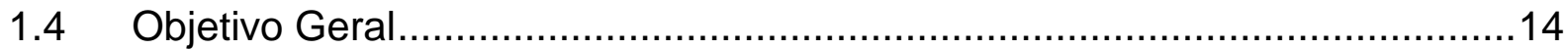

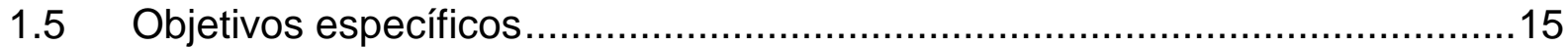

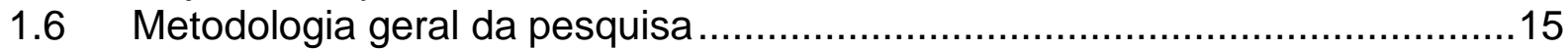

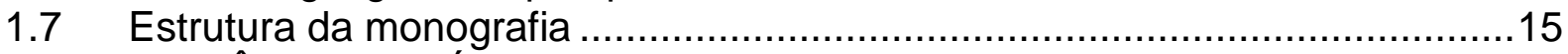

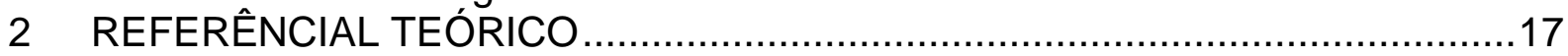

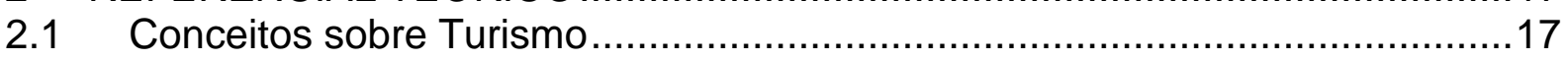

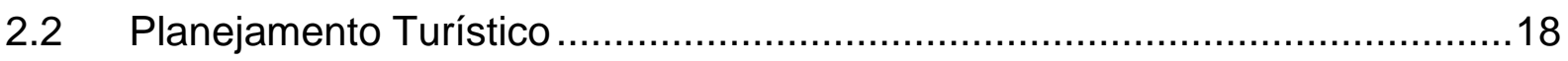

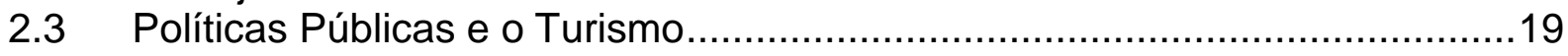

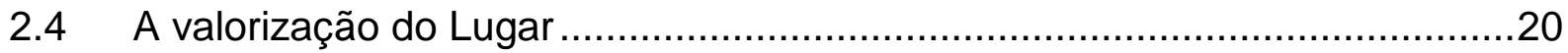

2.5 A educação patrimonial e desenvolvimento do turismo ..............................21

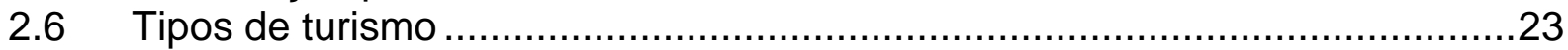

2.6.1 Outros tipos de Turismo ............................................................25

2.7 A importância do patrimônio histórico cultural ..........................................27

3 MÉTODOS E TÉCNICAS DE PESQUISA …..............................................29

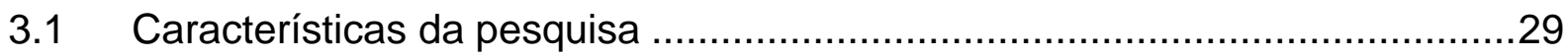

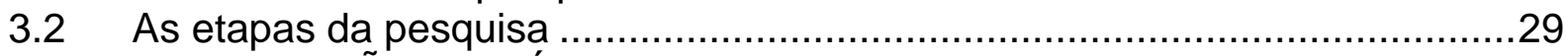

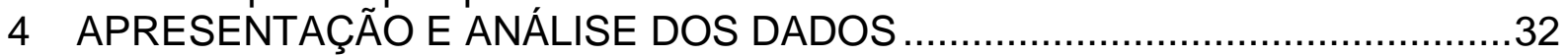

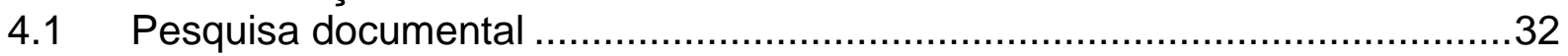

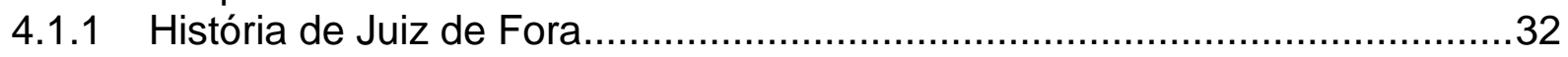

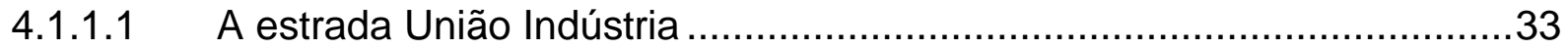

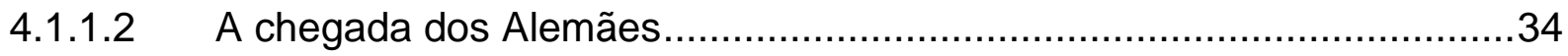

4.1.2 Atrativos histórico culturais de Juiz de Fora..........................................34

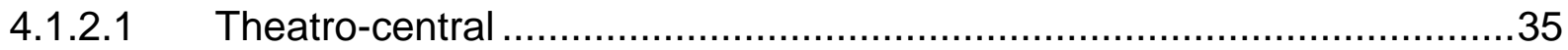

4.1.2.2 Museu Mariano Procópio.................................................................37

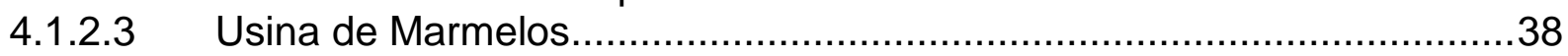

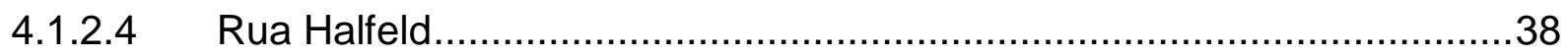

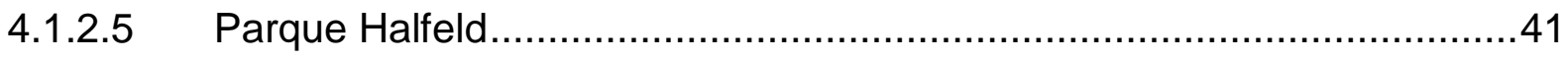

4.1.2.6 Museu Ferroviário.......................................................................

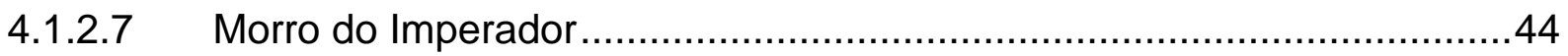

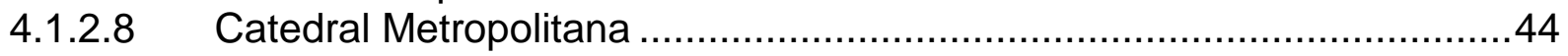

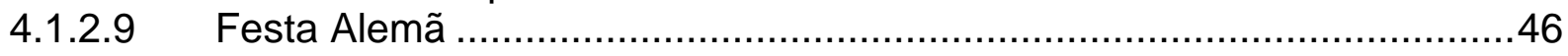

4.1.2.10 Museu Crédito Real.....................................................................46

4.1.2.11 Fazendas históricas de Juiz de Fora ............................................47

4.2 Dados estatísticos a respeito do turismo em Juiz de Fora. .........................51

4.3 O inventário turístico de Juiz de Fora ......................................................54

4.4 O Governo Municipal e os projetos de incentivo ao turismo cultural ..............56

4.5 A participação da comunidade de Juiz de Fora na preservação do patrimônio

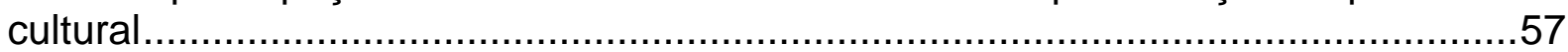

4.5.1 Entrevistas com profissionais do turismo e cultura de Juiz de Fora............58

4.5.1.1 Entrevista com diretor de divisão do Patrimônio Cultural da FUNALFA..58 
4.5.1.2 Entrevista com coordenadora do Curso de Turismo da Universidade Federal de Juiz de Fora

4.5.1.3 Entrevista com o diretor superintendente do Museu Mariano Procópio ..60

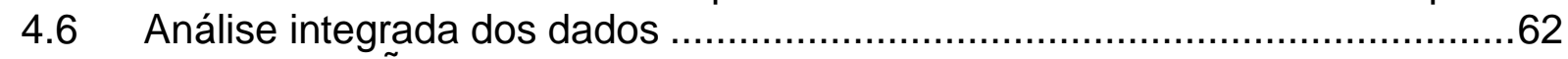

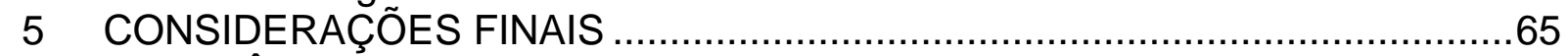

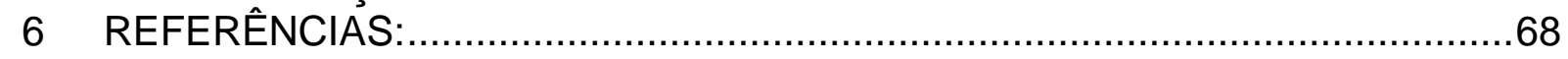




\section{INTRODUÇÃO}

\subsection{Apresentação e delimitação do tema}

O município de Juiz de Fora é considerado um importante centro regional cultural. Possui escolas de arte, escolas de música, corais, cinemas, teatros, espaços culturais, grupos folclóricos e de danças tradicionais além de diversas entidades culturais. A presença da Universidade Federal de Juiz de Fora e de diversas outras faculdades, cursinhos, e cursos técnicos especializados fazem de Juiz de Fora um destino muito comum para estudantes. Além disto, a cidade se destaca também no ramo dos negócios, fator que favorece ao turismo de negócios. Outra razão pela qual Juiz de Fora é conhecida são os eventos que nela acontecem e a movimentação noturna composta por festas universitárias, bons restaurantes, bares, entre outros. $\mathrm{Na}$ lista de atributos juizforanos também são encontrados forte comércio e belas paisagens naturais.

A cidade localizada na Zona da Mata mineira, possui cerca de 500 mil habitantes, e conta com elementos históricos não valorizados e até mesmo não conhecidos pela própria população. Mas apesar de reconhecido potencial turístico, a cidade não aparenta ser apreciada pela sua população e nem mesmo pelos visitantes. A falta de informação juntamente com a má estruturação das atividades e desunião do trade turístico contribui para que a cidade não desenvolva seu potencial.

A proposta de um estudo sobre o turismo histórico cultural e o desenvolvimento de atividades que contribuam para 0 seu desenvolvimento sustentável em Juiz de Fora visa ampliar a qualidade do turismo na cidade e a apresentação de um projeto de planejamento turístico que atenda as expectativas públicas do turismo na cidade, além de valorizar a cultura e a história local.

O desenvolvimento do Turismo sustentável na cidade trás consigo benefícios por ser o turismo uma atividade que vêm se destacado na economia mundial, uma vez que o dinheiro de outros lugares ultrapassa fronteiras, favorecendo a economia do local visitado. Outro fator que torna o turismo atividade relevante são os intercâmbios criados pelos choques sócio-culturais. Para amenizar estes problemas ao final do estudo serão feitas propostas de projetos que integrem a comunidade com objetivo de amenizar impactos sócio-culturais, tentando garantir assim um turismo sustentável. 
O turismo sustentável além dos benefícios citados favorece um melhor acesso à cultura e lazer aos visitantes e também à comunidade local, amplia possibilidades de investimentos devido à maior circulação de capitais. Aumenta a auto-estima da população local com relação à cidade em que vive e facilita a formação de um inconsciente coletivo em busca de desenvolvimento de cidadania, responsabilidade social, melhoria de qualidade de vida entre outras coisas.

\subsection{Descrição da situação problemática}

A cidade possui características históricas que podem ser transformadas em atrativos turísticos, além de condições físicas para a receptividade turística. Porém a falta de organização local juntamente com o despreparo da comunidade, desfavorecem o sucesso da atividade em questão.

Juiz de Fora revela grande importância histórica, possui construções datadas do século XVII , opções de lazer noturnas e diurnas para diferentes idades e classes sociais, e ainda assim as pessoas que ali vivem não consideram que para um visitante Juiz de Fora pode ser interessante, desde que esteja preparada para recebê-lo. E mesmo os turistas que ali estão realizando turismo de eventos ou turismo de negócios, estes precisam ser incentivados a permanecerem na cidade por mais tempo e conhecer melhor as possibilidades de entretenimento presentes no local.

O desinteresse da população juizforana pelo seu patrimônio torna desconhecido para o turista a relevância histórica do local. Muitas vezes a os próprios moradores passam aos turistas (reais e potenciais) uma imagem negativa do lugar, fator este que desestimula o turista eventual a permanecer ali por mais tempo, além disto, o contagia com o pensamento que a cidade não possui coisas interessantes para fazer ou conhecer.

O estimulo à preservação do patrimônio, à limpeza urbana, à diminuição de poluição sonora e visual, à adoção de medidas que controlem melhor o trânsito na cidade, são fatores fundamentais ao desenvolvimento do turismo.

A valorização do lugar é determinante quando se pretende organizar um plano de estruturação do turismo. Um lugar que oferece qualidade de vida a seu morador torna-o satisfeito e causa bem estar no futuro visitante. 
Outro fator é que durante a estada do turista na cidade não há incentivo algum para que este visite algum lugar, como museu, parque, teatro, igreja. Assim, 0 forasteiro que desconhece as oportunidades de passeios não se sente atraído a permanecer em Juiz de Fora.

Considerando estes fatores a questão de pesquisa que se apresenta é: $\mathrm{O}$ potencial turístico histórico cultural de Juiz de Fora está sendo utilizado adequadamente?

\subsection{Justificativa}

O turismo é uma atividade que está se destacando desde o inicio do século XX. A atividade turística aparentemente inofensiva pode gerar muitos impactos para uma localidade. Os impactos citados acima podem ser positivos ou negativos. Por isso a adequação da atividade turística, a estruturação física, e a integração da comunidade podem ser fatores determinantes no sucesso da implementação de um planejamento turístico em uma localidade.

Juiz de Fora é uma cidade onde habitam atualmente mais de 500 mil pessoas, considerada uma cidade de grande porte. No entanto, até hoje com algumas construções antigas como na Vila de Santo Antônio do Paraibuna, como era chamada antes de se tornar cidade. Apesar da proximidade com o Rio de Janeiro e a forte presença dos cariocas na cidade o jeito mineiro (as pessoas são simples e muito hospitaleiras) ainda sobressai na cidade.

Um grande centro urbano, com aparente relevância histórica, com cinemas, teatros, espaços para eventos, espaços culturais, bons restaurantes, museus, bares, vida noturna movimentada, belas paisagens, entre outros, justifica um estudo e uma proposta de planejamento de um desenvolvimento de turismo sustentável.

\subsection{Objetivo Geral}

Para tornar possível uma resposta satisfatória para o problema do estudo em questão, propôs-se o seguinte objetivo geral:

Demonstrar a relevância histórica de Juiz de Fora, propondo alternativas para o desenvolvimento do turismo e valorizando suas características histórico - culturais 


\subsection{Objetivos específicos}

- Levantar os atrativos históricos culturais que favoreçam o turismo da cidade.

- Investigar as condições em que se encontram os atrativos histórico culturais existentes.

- Investigar as condições de infra-estrutura básica e da infra-estrutura de apoio ao turista no local estudado.

\subsection{Metodologia geral da pesquisa}

O desenvolvimento da pesquisa se deu à partir da análise de dados obtidos por a pesquisas desenvolvidas pelo curso de turismo da Universidade Federal de Juiz de Fora, pela Rumos empresa Júnior de Turismo e também pela Prefeitura Municipal de Juiz de Fora, avaliação dos atrativos já existentes e de suas infra estruturas, estudo da existência de projetos já existentes e seus objetivos. A pesquisa foi de caráter qualitativo pois se propôs à interpretar e explicar fenômenos sociais inseridos no contexto turístico de Juiz de Fora.

Os dados e informações foram obtidos por meio de visitas, e entrevistas com pessoas relacionadas ao turismo, história e cultura cidade e coleta de dados preexistentes na Universidade Federal de Juiz de Fora e na Prefeitura municipal de Juiz de Fora.

\subsection{Estrutura da monografia}

O presente estudo está dividido em sete partes básicas que apresentam conteúdos importantes. A primeira parte introduz o tema e apresenta a contextualização do problema de estudo e da justificativa, bem como os objetivos e a metodologia geral. A segunda parte reúne idéias dos principais autores que contribuíram para a realização da pesquisa, e também autores que possuem uma temática semelhante à temática descrita no presente trabalho. A terceira parte do 
trabalho é apresentação da metodologia utilizada no trabalho. Na etapa seguinte é feita a análise dos dados, e em seguida a apresentação dos resultados da pesquisa. Na última parte é apresentada a conclusão e as considerações finais. 


\section{REFERÊNCIAL TEÓRICO}

Neste item será feita uma relação entre os recursos utilizados na realização da pesquisa e as teorias exploradas pelos autores Luiz Renato Ignarra, John Swarbrooke e Eduardo Yázigi. Serão também citadas algumas pesquisas com temas relacionados ao planejamento turístico e ao turismo em Juiz de Fora, além de outras obras também relacionadas.

\subsection{Conceitos sobre Turismo}

O conceito de turismo ainda é muito discutido. Segundo Herman Von Schullard (apud IGNARRA,2001.p.23) a atividade é referida como "a soma de relações e serviços resultantes de uma mudança de residência temporária ou voluntária, motivada por razões alheias a negócios ou profissionais".

Existe também conceitos de autores como o economista austríaco Arthur Bormann (apud IGNARRA, 2001, p.23) que definiu o turismo como:

"O conjunto de viagens que tem por objetivo o prazer ou motivos comerciais, profissionais ou outros análogos, durante os quais é temporária sua ausência da residência habitual"

Talvez a complexidade da atividade inviabilize uma conceituação que realmente determine as ações, mas mesmo que um indivíduo que esteja viajando por motivos que não se enquadram nas definições de turismo, este utiliza de muitos recursos que são viabilizados para turistas, mesmo que a utilização não seja intencional. Mas partindo do conceito de Moesch, (2000.p.19) descrito abaixo é possível uma entendimento amplificado da atividade:

O turismo é uma combinação complexa de inter-relacionamentos
entre produção e serviços, em cuja composição integram-se uma
prática social com base cultural, com herança histórica, a um meio
diverso, cartografia natural. Relações sociais de hospitalidade,
troca de informações interculturais. O somatório desta dinâmica
sociocultural gera um fenômeno, recheado de objetividade/
subjetividade, consumido por milhões de pessoas, como síntese: 0
produto turístico.

Em um outro ponto de vista, podemos considerar que um indivíduo que se desloca de sua residência por qualquer motivo que não seja o lazer ou o turismo pode 
se tornar turista visto que não há nada demais em aproveitar as horas vagas para poder conhecer melhor a cultura do local, ou participar de algum evento, ou visitar algum museu ou patrimônio histórico. Então, mesmo que o objetivo da viagem não seja o turismo ou lazer e cultura, a pessoa que se encontra longe de sua residência pode realizar atividades turísticas.

Muitos autores criam definições para o turismo, mas nenhuma consegue transparecer clareza uma vez que a atividade resulta em transformações sócioeconômicas, tecnológicas e culturais.

\subsection{Planejamento Turístico}

Para Ignarra (2001,p.61), o turismo é uma atividade que tem grande importância no desenvolvimento sócio-econômico, além de possuir grande poder de redistribuição espacial de renda. Se a atividade não for planejada adequadamente ela tende a promover um crescimento desordenado que traz consigo efeitos nocivos ao lugar, tais como: efeito inflacionário nas regiões receptivas (no caso em cidades em que o turismo está relacionado à estação ou temporada), aumento da poluição das águas, visual ou do ar. No ponto de vista cultural a contribuição também pode ser negativa, acredita-se que seja relevante para o caso de Juiz de Fora, (uma vez que a proposta de planejamento turístico não tem como objetivo transformar o turismo em principal atividade econômica do local, mas apenas canalizar um possível potencial existente para uma atividade que valorize a cultura municipal e concomitantemente possa trazer benefícios sociais e econômicos para a cidade).

Ignarra (2001,p.61) também expõe que o planejamento do turismo se faz necessário para acelerar e maximizar os efeitos positivos da atividade e suavizar os efeitos negativos.Além disso o planejamento da atividade turística se mostra, portanto, como um poderoso instrumento de incentivo ao desenvolvimento de uma comunidade.

O planejamento consiste na definição dos objetivos, na ordenação dos recursos materiais e humanos, na determinação dos métodos e formas de organização, no estabelecimento das medidas de tempo, quantidade e qualidade, na localização espacial das atividades e outras especificações necessárias para canalizar racionalmente a conduta de uma pessoa ou grupo. (IGNARRA, 2001,p.62). 
O planejamento turístico de qualidade deverá estudar também as condições de lazer e cultura oferecidas para os moradores do lugar. Este fator é determinante na satisfação da comunidade, e tem grande importância para o desenvolvimento do turismo e está exposto abaixo:

As cidades não se preocupam muito com o lazer nem com as necessidades de relaxamento de seus habitantes. A maioria são cidades de trabalho, incompatíveis com a vida plena. O processo de urbanização não para com todas as implicações nefastas ao homem, embora já alguns anos todos falam em tornar as cidades mais habitáveis. Continuo a implantação de lugares de trabalhos nos centros. Os preços dos terrenos aumentam. O espaço habitável se reduz. As cidades transbordam e invadem o campo. As vias de comunicação entre cidade e campo de desenvolvem. Os esforços desesperados para salvar alguns espaços verdes e implantar algumas instalações para o lazer não alteram a situação: as condições de moradia e a qualidade de vida citadina degradamse a olhos vistos. Uma tripla fragmentação sucede-se à bipolarização do homem: trabalhar aqui - morar ali - repousar em outro lugar. As responsabilidades são transferidas para o exterior. Ainda que diretamente ligado à urbanização, o custo do lazer não é levado em consideração pelas cidades, que não se sentem responsáveis pelo mesmo e nem 0 assumem (KRIPPENDORF,2003,p.37)

\subsection{Políticas Públicas e o Turismo}

O desenvolvimento da atividade turística em um lugar não depende apenas de seus atrativos turísticos, mas também de um planejamento adequado e do bom entrosamento entre o poder público e o interesse privado.

Para Barreto (2003,p.32) o papel das políticas públicas relacionadas ao turismo é propiciar o desenvolvimento harmônico da atividade turística. O estado deve construir a infra estrutura de acesso e a infra estrutura básica urbana - que também atende à população local e prover uma super estrutura jurídico administrativa (secretarias e similares) cujo papel é planejar e controlar os investimentos que o estado realiza- que permitem o desenvolvimento da iniciativa privada, encarregada de construir os equipamentos e prestar serviços - que retornem na forma de benefícios para toda sociedade.

Apesar de a atividade turística ser uma das que mais está se destacado economicamente nos últimos anos não existem pesquisas suficiente a respeito do turismo. Este fato é citado 
A ciência política tem produzidos poucos estudos sobre o turismo. Isso parece ser atribuído ao mesmo motivo pelo qual não há muitos estudos de antropologia ou de sociologia sobre o tema: o turismo não é considerado um objeto sério de pesquisa.

(BARRETO;BURGOS;FRENKEL, 2003, p.34)

Ao tratarmos de turismo, a maioria das pessoas possui uma idéia equivocada do assunto. O pensamento predominante é de lugares cheios com características do turismo de massa, outra característica comum do pensamento errôneo é que o turismo tem que trazer resultado econômico favoráveis a curto prazo. No entanto para que o turismo se desenvolva equilibradamente são necessários projetos que sejam desenvolvidos a médio e longo prazo.

O planejamento racional do turismo implica a existência de políticas públicas: de saneamento, saúde, transporte, de proteção ao consumidor, de distribuição de renda.Esse tipo de planejamento exige geralmente objetivos de médio e longo prazos, e imposição de limites às áreas de atuação e ao lucro imediato, o que é inaceitável para os capitais que operam nessas áreas de negócios.(BARRETO;BURGOS;FRENKEL, 2003, p.36)

O desenvolvimento de políticas de incentivo ao turismo são muito importantes para o sucesso da atividade. Outro fator que é bastante importante é a continuidade dos projetos pelo governo. É muito comum mudanças e extinção em relação a projetos iniciados em gestões anteriores em prefeituras. A falta de seguimento de projetos de longo prazo prejudica os resultados esperados do turismo em um lugar.

\subsection{A valorização do Lugar}

Yázigi (2002,p.29) apresenta críticas às definições de Lugar e as considera como insuficientes para entender e para planejar nas escalas do cotidiano e nas escalas do turismo. Para ele o espaço geográfico precisa ser marcado por um conjunto de características, materiais ou não, independente do que um observador possa qualificar de virtudes, seja qual for a principal atividade econômica realizada no lugar.

Usualmente, a personalidade, ou o conjunto de identidades do lugar, na vida cotidiana, tem sido entendido como relações sociais, instituições, arquitetura, urbanismo e toda a cultura material; costumes e vários outros itens que se repetem 
em todas as partes, como bem nos dão conta a sociologia, a antropologia e etnologia. Neles reconheço importantes e indispensáveis sustentáculos do grupo.

Yázigi (2002,p.30) ressalta também que não cabe ao planejador fabricar um "mundo" rico e expressivo, mas reconhecer sua dimensão para não destruí-lo. Em outras palavras, o autor defende a postura de um planejamento que garanta 0 desenvolvimento sustentável de uma comunidade turística.

Uma das mais importantes características para a definição de um lugar é o que se refere ao patrimônio e à cultura deste. E estas particularidades são muito favoráveis ao desenvolvimento do turismo. Obviamente o planejamento deste turismo deve ser bem estruturado para garantir o desenvolvimento adequando-o ao modelo de sustentabilidade.

A atividade turística pode trazer muitos benefícios para as regiões de destino isto porque além de benefícios econômicos, o desenvolvimento do turismo é uma atividade capaz de estimular o resgate de uma cultura local esquecida, valorizar, enriquecer e elevar a auto estima da comunidade local em questão. Em contrapartida, seu crescimento desordenado pode provocar danos irreversíveis às culturas locais como também alguns fatores internos podem atuar como inibidores do turismo, tais como violência, miséria, infra-estrutura precária, má conservação do patrimônio natural e cultural, comprometendo o desenvolvimento em questão.

A educação patrimonial pode ser uma opção na tentativa de garantir o desenvolvimento de um turismo sustentável em Juiz de Fora.

\subsection{A educação patrimonial e desenvolvimento do turismo}

Planejar e desenvolver o turismo é uma tarefa complicada Swarbrooke, (2002,p.69) defende que o desafio do turismo sustentável está em administrar o turismo nas destinações de maneira a maximizar os impactos positivos, e ao mesmo tempo reduzir os negativos. Entretanto, cada destinação é diferente das outras e os impactos reais variam, segundo os diferentes tipos de destinações, dependendo:

- da época em que a estação turística foi desenvolvida e de como o empreendimento foi planejado inicialmente; 
- dos tipos de turismo e dos turistas atraídos pela destinação;

- do grau de desenvolvimento da indústria turística local e de suas relações com organizações turísticas sediadas no exterior;

- da política do setor público.

O desenvolvimento do turismo deverá buscar mecanismos de atuação que tornem predominantes os benefícios sócio-culturais a longo prazo quando relacionados aos ganhos em curto prazo.

Desta forma se o planejamento do turismo tiver como objetivo a sustentabilidade, será evitada a danificação irreversível do patrimônio turístico e da infra-estrutura turística e de apoio ao turista, além de minimizar os custos e não interferir no cotidiano do morador do local.

Em Juiz de Fora a atividade turística ainda não está consolidada e a cidade possui muitos pontos a favor para um desenvolvimento turístico de qualidade. Trata-se de um grande centro urbano, com atividade econômica ativa e distinta do turismo, bons atrativos, espaços para lazer. Porém para transformar uma cidade em um local turístico é importante que exista um estudo sobre satisfação do morador a respeito da infra estrutura básica composta por; acessos, saneamento, energia elétrica, comunicação, vias urbanas de circulação, abastecimento de gás, controle de poluição, capacitação de recursos humanos, segurança. Além destes a qualidade da infra estrutura de apoio ao turismo que agrupa serviços como; transportes, serviços bancários, serviços de saúde, segurança, informação comunicação, e comércio turístico (lojas de conveniência, artesanatos, produtos típicos).

O desenvolvimento do turismo histórico cultural em uma cidade como Juiz de Fora deve apoiar-se em medidas educacionais: Educação Ambiental natural e patrimonial.

Atualmente, já se sabe que para que o desenvolvimento do turismo não degrade o patrimônio da cidade receptora, ele deve ser conduzido adequando-se aos recursos físicos e sócio-culturais da região receptora. Para que esta medida seja tomada e respeitada em uma localidade, é muito importante a intervenção do poder público.

RODRIGUES(2007.p.15) afirma também que "além do valor cultural específico, do ponto de vista do turismo cultural, os bens materiais possuem um valor 
diferente pois passam a ser objetos indispensáveis, cujo consumo é a base de sustentação da própria atividade. Sendo assim, a valorização ultrapassa sua importância para a qualidade de vida das populações locais."

A atividade turística é, portanto, produto da sociedade capitalista industrial e se desenvolveu sob o impulso de motivações diversas, que incluem o consumo de bens culturais. O turismo cultural, tal qual o concebemos atualmente,implica não apenas a oferta de espetáculos ou eventos, mas também a existência e preservação de um patrimônio cultural representado por museus, monumentos e locais históricos" (RODRIGUES,in PISK;FUNARI,2007,p.15)

\subsection{Tipos de turismo}

O turismo é uma atividade que possui subdivisões para melhor entendimento, aproveitamento e estudo. Dentro do universo do turismo encontramos : O Turismo Rural, o Turismo de Eventos, Turismo de Negócios, Turismo de praia e sol, Ecoturismo, Turismo religioso, entre outros. Swarbrooke e Horner, (2002), conceituam o turismo cultural e alguns outros tipos de turismo que são interessantes para o estudo do Potencial Turístico Histórico cultural em Juiz de Fora.

Turismo cultural

"Turismo Cultural compreende as atividades turísticas relacionadas à vivência do conjunto de elementos significativos do patrimônio histórico e cultural e dos eventos culturais, valorizando e promovendo os bens materiais e imateriais da cultura".(BRASIL,2006,p.10)

Swarbrooke e Horner (2002.p.65) relacionam o turismo cultural com o turismo de interesse especial, porém é mais amplo. Sustenta-se pelo desejo de conhecer outras culturas, artesanatos, histórias.Eles afirmam também que o turismo cultural abrange muitos elementos do mercado do turismo, incluindo:

- Visitas a atrações e destinações de legado cultural e visitas a festivais tradicionais; 
- Férias motivadas por um desejo de provar a comida e o vinho nacional, regional, ou local;

- Assistir eventos esportivos tradicionais e participar de atividades de lazer locais;

- Visitar locais de trabalho, sejam eles fazendas, centros de artesanato ou Fábricas.

A cartilha Turismo cultural elaborada pelo Ministério da Cultura ressalta que o desenvolvimento do turismo cultural $\mathrm{e}$, conseqüentemente, dos respectivos produtos deve estar associado a atrativos e equipamentos com adequadas condições de visitação. Recomenda-se então a observação dos seguintes aspectos na estrutura física.

- Verificar se os bens culturais são tombados e quais as implicações para a gestão do fluxo de visitantes

- Avaliar o estado de conservação e a necessidade de restauração, recuperação e conservação do bem

- Viabilizar a restauração e a manutenção

- Observar as condições de acesso ao bem cultural que se pretende atrativo turístico

- Providenciar a sinalização turística e interpretativa do patrimônio cultural

- Planejar e implementar rotas de visitação no atrativo e estrutura de recepção,saídas de emergência, toaletes e, em alguns casos, lanchonetes e restaurantes

- Estabelecer a capacidade de suporte de cada atrativo, observando os preceitos de preservação e conservação do patrimônio

- Conceder incentivos que permitam aos proprietários de bens considerados patrimônio, promoverem a preservação e conservação

- Prever espaços para a realização de apresentações, oficinas e outras atividades culturais

A manutenção das condições físicas dos atrativos deve ser adequada a cada tipo de visitação de modo a garantir a integridade do atrativo e a qualidade da experiência.

Proporcionar experiências significativas nos atrativos culturais é um desafio para os gestores - é preciso criatividade no oferecimento de informações e atividades que levem em 
consideração as possibilidades do turista aprender, contemplar e entreter-se. (BRASIL, 2006.p.22)

Dentro do turismo cultural é possível encontrar algumas subdivisões:

- Turismo religioso: O turismo religioso envolve visitas a lugares de importância religiosa, ou eventos religiosos, como comemorações de dias santos. O turismo religioso por sua vez pode estar relacionado ao turismo de saúde, muitas pessoas visitam santuários modernos na esperança de cura para suas doenças e agradecer a cura destas.

- Turismo educacional: São as viagens que tem como característica o interesse em algum aprendizado. $O$ autor explica que existem dois tipos: Intercâmbios de estudantes, neste caso os jovens viajam para outros países a fim de estudar e aprender mais sobre a língua e a cultura de outros povos, o outro tipo é conhecido como turismo de férias com interesse especial cuja principal motivação de quem as realiza é aprender algo novo.

- Turismo de eventos: Este pode estar relacionado à manifestações culturais locais.

\subsubsection{Outros tipos de Turismo}

Existem também tipos de turismo que não estão inseridos em um contexto cultural, mas que pode viabilizar o interesse pelo turismo cultural uma vez que 0 turista se encontra em determinado local por motivos diferentes da realização de turismo cultural, e podem ser estimuladas à aproveitar a oportunidade e conhecer melhor o legado cultural de uma cidade ou região. São eles:

Visitas a amigos e parentes: É o turismo motivado pela necessidade em rever amigos e parentes que se separaram em conseqüência de mudança no estilo de vida, profissionais, financeiras entre outras.

Turismo de negócios:O turismo de negócios é uma das formas de turismo mais antigas, porém a atividade foi transformada pelo tempo. Até o presente século, as viagens de negócios estiveram relacionadas em grande parte exclusivamente com vendas, transporte de mercadorias clientes residentes fora da área de produção, o que envolvia apenas 
- Visitas a clientes potenciais;

- Transporte de mercadorias ao cliente.

No passado, devido à precariedade do sistema de transportes os negócios feitos em pequenas distâncias eram mais comuns. Mas também realizava-se negócios a longa distância utilizando navios.As feiras de negócios que se caracterizam pela união de pessoas de uma região, ou de um ramo especifico da indústria com objetivo de vender e trocar novidades de seu setor profissional, o costume foi trazido da Idade Média.

O crescimento do turismo de negócios se deu após à segunda guerra mundial estimulado por:

- Melhorias nas tecnologias de transporte;

- Ascensão da economia global;

- O crescimento de blocos comerciais supra nacionais, como, por exemplo, a União Européia, e o acordo comercial entre os Estados Unidos, o Canadá, e o México( NAFTA).

- O esforço realizado por governos para atrair turistas de negócios que gastam elevadas quantias.

Atualmente o turismo de negócios não diz respeito apenas às viagens de vendas e ao transporte de mercadorias mas envolve também conferências para a troca de informações, eventos dispendiosos para o lançamento de novos produtos, fins de semana de sobrevivência para motivar ou recompensar a equipe, e cursos de treinamento intensivo.

Turismo de saúde

Inicialmente o Turismo de saúde era sinônimo de exploração das propriedades medicinais de fenômenos naturais como; fontes de águas minerais, piscinas naturais de águas terapêuticas.

Outra forma de turismo de saúde é o deslocamento das pessoas do local de residência em busca de clínicas com tratamentos especializados ou a procura de determinados médicos. 


\title{
2.7 A importância do patrimônio histórico cultural
}

O patrimônio histórico cultural de um lugar deve ser conservado, para possibilitar um relacionamento das pessoas com a história e cultura de determinado lugar.

\begin{abstract}
A palavra patrimônio indica uma escolha oficial, o que envolve exclusões; também significa algo construído para ser uma representação do passado histórico e cultural de uma sociedade.

Além disso, ao falarmos "patrimônio", em geral, nos referimos a uma parte apenas dos bens culturais, o patrimônio históricoarquitetônico. Essa noção foi abarcada por outra, mais ampla, a de patrimônio cultural, que envolve ainda a de patrimônio ambiental, uma vez que hoje concebemos o ambiente como um produto da ação dos homens, portanto, da cultura.

A construção do patrimônio cultural é um ato que depende das concepções que cada época tem a respeito do que, para quem e porque preservar. A preservação resulta, por isso, da negociação possível entre os diversos setores sociais, envolvendo cidadãos e poder público. O significado atribuído ao patrimônio também se modifica segundo as circunstâncias de momentos. (RODRIGUES,in PISK;FUNARI,2007. p.16)
\end{abstract}

Conhecer o passado auxilia a compreensão do presente. A preservação do patrimônio arquitetônico e também das manifestações culturais de um lugar deve manter as características originais e as tradições para que o interesse de moradores e turistas seja constante. Mantendo sua originalidade o Patrimônio histórico cultural poderá ser também utilizado para ilustrar conteúdos escolares, facilitando e estimulando o aprendizado de crianças e adolescentes.

A interpretação adequada do patrimônio cultural é fundamental para a preservação deste por parte da comunidade e dos turistas. Para que aconteça o Ministério da Cultura aconselha que os atrativos culturais devem estar acessíveis quanto aos seguintes aspectos:

- Espacial ( localização, acesso, sinalização, informação)

- Temporal (datas e horários possíveis de desfrute)

- Econômico (preços e tarifas para o desfrute)

- Psicológico, afetivo e intelectual (relacionado à forma como o atrativo pode ser

- contextualizado e apreciado completamente no seu contexto) 
A observação desses aspectos é que dão conteúdo para a estruturação de produtos turísticos em geral. No caso do Turismo Cultural, a abordagem psicológica, afetiva e intelectual torna-se referência e diferencial, sob a qual se fundamentam os principais mecanismos facilitadores da inter-relação turista e comunidade.

Estas relações entre turistas e comunidade citadas em Turismo Cultural (Ministério da cultura) são importantíssimas para o desenvolvimento sustentável da atividade turística 


\section{MÉTODOS E TÉCNICAS DE PESQUISA}

Neste capítulo foi apresentada a metodologia utilizada para a realização da pesquisa e análise dos dados.

\subsection{Características da pesquisa}

O presente estudo está relacionado ao potencial turístico de Juiz de Fora. Para investigação do tema foram utilizados dois tipos de pesquisa:

A pesquisa quantitativa foi do tipo pesquisa documental pois foi desenvolvida a partir de artigos, inventários e trabalhos já existentes. E a qualitativa que buscou entender, interpretar e explicar a existência de um potencial turístico em Juiz de Fora e adaptá-lo de forma a incentivar o desenvolvimento da atividade e o estímulo ao resgate cultural e valorização do patrimônio pelos juizforanos. A situação será estudada e comparada a outras situações semelhantes. A pesquisa terá caráter explicativa e descritiva.

A uma etapa exploratória da pesquisa proporcionou à pesquisadora maior proximidade com o problema. A familiarização do pesquisador com o assunto auxiliou com a percepção do mesmo e na descoberta de novas idéias.

\subsection{As etapas da pesquisa}

Primeiramente foi feita uma pesquisa bibliográfica a respeito do surgimento e da história da região de Juiz de Fora e seus traços culturais, tendo grande importância pois auxiliou no conhecimento dos patrimônios históricos da cidade. Tal fase buscou identificar fatores que determinam traços culturais. Foram utilizados livros e artigos científicos.

Posteriormente na etapa exploratória da pesquisa foram realizadas entrevistas com pessoas que possuem experiência no assunto tratado e estão diretamente envolvidas com as atividades turísticas de Juiz de Fora. A pesquisa possibilitou a obtenção de informações sobre o assunto.

$\mathrm{Na}$ entrevista foram feitas três perguntas determinantes: 
1) O Senhor(ou Senhora) acredita que exista um potencial Turístico Histórico Cultural em Juiz de Fora?

2) Se sim, você considera que o potencial turístico existente é utilizado?

3)Se o órgão a que o entrevistado está representando na entrevista possui algum projeto que tenha como objetivo a valorização histórico cultural, em Juiz de Fora.

A realização das entrevistas foi importante para proposição de hipóteses relacionadas ao tema.

As pesquisas qualitativas podem ser diferenciadas quanto a sua forma, e para o universo de definições de Godoy, 1995 a pesquisa aqui apresentada possui duas características que a define, são elas: o ambiente natural como fonte direta de dados; e seu caráter descritivo.

Outro momento nesta fase da pesquisa descrita acima foi a pesquisa documental de inventários e projetos que se caracterizou por não terem recebido tratamento analítico, e ainda podem ser reelaborados de acordo com os objetivos do trabalho. Os documentos utilizados foram inventários e projetos destinados à valorização da cultura e do turismo. Esta etapa do trabalho foi realizado com a colaboração da Prefeitura Municipal de Juiz de Fora. Alguns dados estatísticos relacionados ao turismo e a cultura em Juiz de Fora foram pesquisados na Universidade Federal de Juiz de Fora.

Mesmo sendo uma pesquisa qualitativa, a complexidade do assunto tratado não descarta a possibilidade da utilização de dados que mesclem informações de pesquisas qualitativas e quantitativas. Neves (1996,p.2) defende que "Os métodos qualitativos e quantitativos não se excluem. Embora difiram quanto à forma e à ênfase, os métodos qualitativos trazem como contribuição ao trabalho de pesquisa uma mistura de procedimentos de cunho racional e intuitivo capazes de contribuir para melhor compreensão dos fenômenos. Podem se distinguir o enfoque qualitativo do quantitativo, mas não seria correto afirmar que guardam relação de oposição".

A última etapa consistiu em coleta de informações através de entrevistas com pessoas que estão inseridas no contexto valorizado pelo estudo referente ao turismo, a cultura e ao desenvolvimento sustentável deste em Juiz de Fora. O objetivo foi o questionamento a respeito de projetos e planos para o Turismo. 
Entre os entrevistados foi possível destacar o responsável pelo turismo e o responsável pela cultura da cidade, historiadores e educadores que fossem engajados na promoção e educação ambiental e patrimonial. Aqui, a pesquisadora buscou analisar o interesse de conhecedores e a opinião destes a respeito do assunto tratado.

Para garantir a veracidade das pesquisas e facilitar a transcrição para o trabalho, todas as entrevistas foram gravadas pela pesquisadora. 


\section{APRESENTAÇÃO E ANÁLISE DOS DADOS}

As informações neste capitulo apresentadas foram retiradas de livros, artigos, site da prefeitura municipal de Juiz de fora, jornais, e documentos referentes à história de Juiz de Fora existentes nos locais pesquisados e entrevistas com pessoas relacionadas com o meio turístico histórico cultural.

\subsection{Pesquisa documental}

\subsubsection{História de Juiz de Fora}

A região em que situa se Juiz de Fora e outras cidades da Zona da Mata Mineira foi conhecida durante dois séculos desde o descobrimento do Brasil, como “ Áreas proibidas dos Sertões Leste".

Nas áreas de exploração metálica os povoados cresciam e novas comunidades surgiam, mas aqui nas divisas com a Província do Rio de Janeiro permanecia tudo intocado.

O caminho percorrido pelo ouro, das minas até a cidade do Rio de Janeiro (Capital do Brasil) era muito longo e cansativo e facilitava a fuga dos escravos vindos para o Brasil para trabalhar na mineração. Para encurtar as distâncias Garcia Rodrigues Paes, primogênito de Fernão Dias, se dirigiu ao governador com o plano de abrir um caminho seguindo a linha do Rio Paraibuna. Surgiu então o caminho Novos Campos das Gerais. Seguindo a Trilha do Rio Paraibuna foi descoberta a região do município que depois teria por topônimo Juiz de Fora. Antes, o topônimo era Paraibuna e a Vila, depois cidade, Santo Antônio do Paraibuna.

Até 1837 funcionava o Caminho Novo, com a estrada do Paraibuna e, a partir de 1861, a Estrada de Rodagem União e Indústria. O movimento se deslocou para o lado direito do Rio Paraibuna, onde surgiu, cresceu e floresceu o povoado de Santo Antônio do Paraibuna, passando mais tarde a Vila de Santo Antônio do Paraibuna, e sendo elevado à cidade em maio em 2 de maio de 1856, e por iniciativa do Barão de São Marcelino, foi sancionada a Lei que denomina definitivamente o nome da cidade como Juiz de Fora.

Santo Antônio do Paraibuna posteriormente mudou de nome devido a um fato histórico ocorrido por volta de 1710. a concessão das três sesmarias. sendo uma 
delas concedida ao sesmeiro João de Oliveira, que pouco tempo depois a vendeu ao Juiz de Fora da Cidade do Rio de Janeiro, dr. Luís Fortes Bustamante de Sá. O Juiz de Fora, não era assim chamado por ser Juiz de Fora da região do caminho novo, mas sim por ser o Juiz de Fora da cidade do Rio de Janeiro. E foi ele o responsável pelo nome novo nome da cidade Santo Antônio do Paraibuna, que até os dias de hoje é chamada de Juiz de Fora.

Para o historiador juiz-forano Douglas Fazolatto:

O Caminho novo começa efetivamente a escrever a história de Juiz de Fora." Esta nova rota, foi determinante para a ocupação territorial, pois no século XVIII, a partir das sesmarias começaram a surgir os povoados. Mas o povoamento às margens do Paraibuna não se deu instantaneamente após este acontecimento.(FAZOLATTO in BASTOS;2004,p.61)

\subsubsection{A estrada União Indústria}

Juiz de Fora, recém criada estava passando por uma fase de grande desenvolvimento agrícola com a produção de café, nesta época a exportação cafeeira estava movimentando a economia do país e a Zona da Mata Mineira possuía condições favoráveis para o cultivo do produto. No entanto um complicador da época era o transporte da cargas. Visto que o acesso pelo caminho novo não colaboravam com o volume da produção de café local.

Mariano Procópio Ferreira Lage propõe ao Governador Imperial Dom Pedro II, a construção e conservação da estrada de rodagem, que seria totalmente custeada por Mariano Procópio que obteve a autorização para tal realização em 07 de agosto de 1852.

Fundada a Companhia União Indústria, prosseguiu-se a construção da nova estrada, que tinha início no atual bairro Mariano Procópio, passando pelo Morro do Gratidão ( Atual avenida dos Andradas, e também conhecida como "Morro da Glória") e quando atingia o Largo do Riachuelo, desviava da Cidade do Paraibuna (da rua São Sebastião até o Alto dos Passos). Esse desvio deu origem à atual Avenida Getúlio Vargas.

No dia 23 de Junho de 1861 é inaugurada a Estrada União Indústria que separava em 144 quilômetros Juiz de Fora de Petrópolis. A construção da rodovia União Indústria foi determinante na instalação de uma Colônia de imigrantes Alemães, responsáveis pelos primeiros empreendimentos industriais. 


\subsubsection{A chegada dos Alemães}

Parte importante também na história de Juiz de Fora foi a chegada dos Alemães. Os imigrantes alemães chegavam em turmas e vinham para trabalhar na Companhia União e Industria.

Neste período a cidade acabara de se emancipar de Barbacena ( ocorrido em 1850). Então, em 1858 chegaram quase 2.000 imigrantes alemães que vieram trazidos pelos esforços do engenheiro Juizforano, Mariano Procópio Ferreira Lage.

A ultima turma aqui chegou a 20 de agosto de 1858. Installada a colônia, vinte mezes depois tinha população de 1.112 almas, segundo o relatório da presidência de Minas, de 22 de abril de 1860.Em 1870 tinha 1.258 habitantes, sendo 1.147 allemães e 111 brasileiros, todos laboriosos e de repreensível procedimento. Possuía escolas primárias para ambos os sexos, revelando em todos os sentidos notável prosperidade. (ESTEVES,1915, p.169).

Os alemães vieram para Juiz de Fora em busca de vida nova em terras onde pudessem cultivar verduras, frutas e legumes. Mas ao aqui chegarem, a decepção. A terra era desfavorável ao cultivo. O que colhiam, mal dava para o sustento da própria família.

Após a construção da estrada União Indústria os trabalhadores foram trabalhar nas indústrias que ainda eram novas na cidade: Mecânica, Cervejaria, Serrarias, Marcenarias, Serralherias, Tecelagens, dentre outras.

O alemães se instalaram principalmente nos Bairros São Pedro e Borboleta, onde até nos tempos atuais muitos descendentes ainda vivem.

(...) com machados, foices e enxadas, derrubaram e desmataram. Com materiais fornecidos pela União Indústria, construíram suas moradias em regime de multirão e aos poucos foram povoando a Colônia de cima, hoje Bairro São Pedro e a Colônia de baixo, atual bairro Borboleta. (CLEMENTE,2008. p 97.)

Atualmente, existem na cidade grupos de danças alemãs junto às comunidades descendentes que se apresentam em eventos culturais em Juiz de Fora e também em outras localidades.

\subsubsection{Atrativos histórico culturais de Juiz de Fora}

São variados os espaços e as instituições históricas e culturais importantes encontrados em Juiz de Fora. Possui vários Museus como Museu de Arqueoastronomia, Museu de História Natural, o Museu do Banco Crédito Real, o 
Museu do Folclore, o Museu Ferroviário, o Museu do Rádio, o Museu da Usina de Marmelos Zero. Abaixo, alguns serão melhor explicados:

\subsubsection{Theatro-central}

Inaugurado em 1929, é tido como símbolo do período áureo de Juiz de Fora. Para a época, era considerado sofisticado e inovador devido à construção "moderna" e à tecnologia. A partir de sua criação, a princesa de Minas passa a ter estrutura receptiva para grandes espetáculos nacionais e estrangeiros. Foi criado no estilo italiano, considerado ideal para a apresentação de óperas e operetas.

Conforme relatos do Jornal Tribuna de Minas, do dia 29 de março de 2009, a proposta de erguer o Cine-Theatro Central foi levada à construtora Pantaleone Arcuri pela Companhia Central de Diversões(CCD), fundada em 1927 pelos sócios Francisco Valadares, Químico Corrêa, Diogo Rocha e Gomes Nogueira.

Segundo o filho do proprietário da construtora contratada Arthur Arcuri relata para o Jornal Tribuna de Minas:O custo do projeto superou as expectativas e a obra não poderia ser feita. Aí papai decidiu entrar como sócio para completar a quantia necessária.

O Cine-Theatro Central foi o primeiro edifício da cidade a ser construído de concreto armado, um tipo de tecnologia totalmente nova nos anos 1920. O teatro também impressionava por causa do imenso vão de $36 \mathrm{~m}$, um espanto para aquela época. Consta que a ousadia do projeto impressionava até os trabalhadores da obra.

Apesar de ser construído focando as óperas italianas, o cinema foi durante muitos anos a atração principal e mais popular do Central, que é até hoje mais conhecido como Cinema Central. No entanto a popularidade das sessões não tornou obscura as apresentações teatrais.

A diversificação de público contava com sessões matutinas para infantes e até mesmo sessões exclusivas para mulheres. A divulgação era feita em cartazes gigantescos em sua fachada, como mostra a figura 1. 


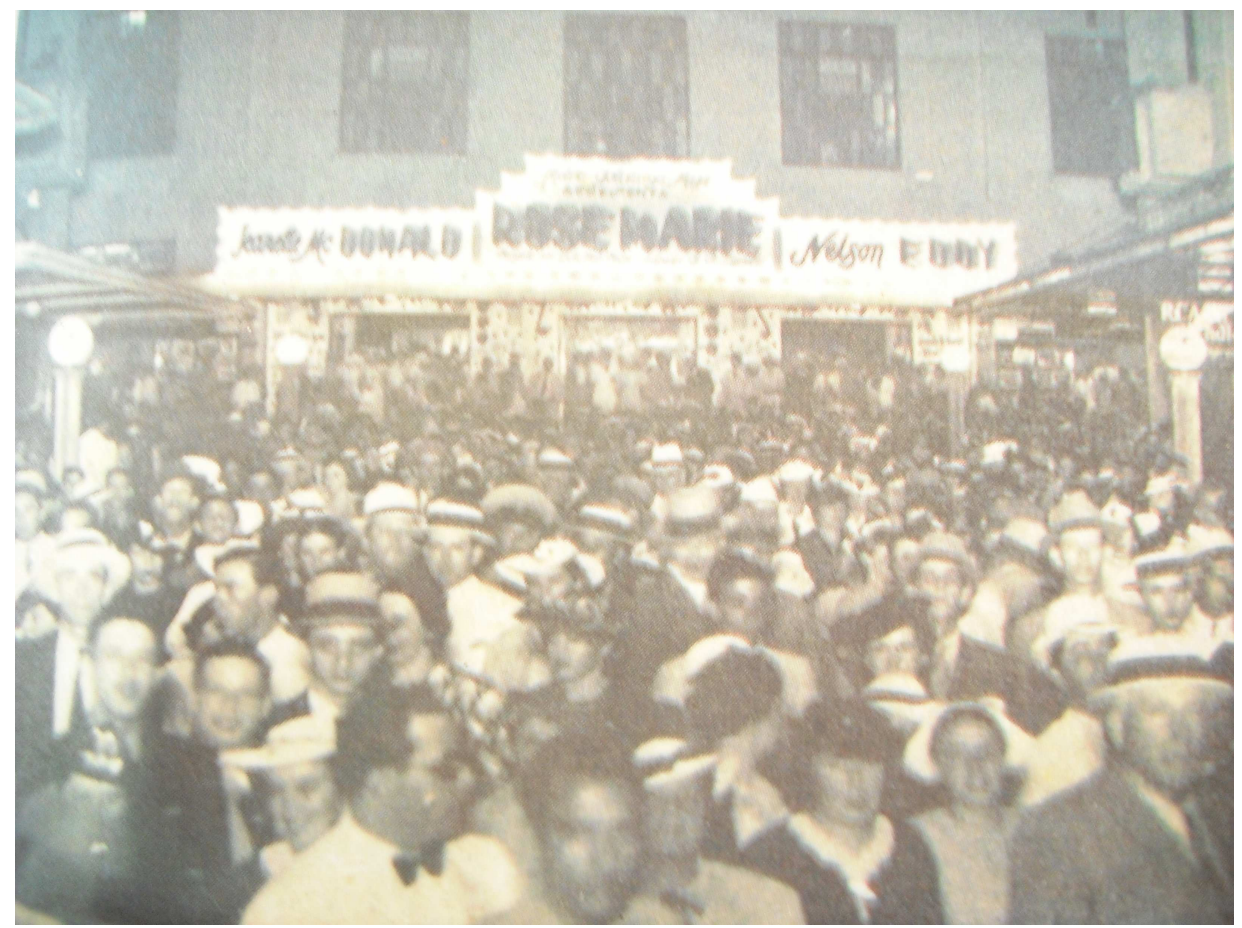

Figura 1:Fachada Cine-Theatro Central década de 30: Final de sessão Fonte: Neves (1998)

Recentemente o Central ( como é conhecido) completou oitenta anos, e em sua oito décadas de trajetória procurou sempre adaptar-se às necessidades e aos modismos de cada época. Nas décadas de 40 e 50 abrigou programas de auditório da rádio Industrial. Já nos anos 1960 e 1970, o teatro cedeu lugar a festivais de música. Posteriormente passou por um período crítico de decadência e em 1994 foi adquirido pela Universidade Federal de Juiz de Fora incentivado pela classe artística intelectual. Na mesma época o imóvel foi tombado pelo Instituto do Patrimônio Histórico e Artístico Natural (IPHAN). Atualmente ele está completamente recuperado, é destinado a eventos como; formaturas, shows, peças teatrais, entre outros.

O teatro possui 1.851 lugares, divididos entre platéia, o balcão nobre, as galerias e os camarotes. A boca de cena possui $12 \mathrm{~m}$ de largura, $9 \mathrm{~m}$ de altura e $10 \mathrm{~m}$ de profundidade. O palco possui um desnível de $30 \mathrm{~cm}$ e é habitado pelas bambolinas (panos pretos que se estendem no topo, na horizontal), rotunda e ciclorama (panos preto e branco, que cobrem todo o fundo do palco) e pernas ( panos que se estendem nas laterais, na vertical. 


\subsubsection{Museu Mariano Procópio}

Em Esteves (1915), afirma que o Comendador Mariano Procópio mandou construir o seu castelo rodeado por um denso jardim inglês repleto de ornamentação rústica, lagos, ilhotas e arvoredos. Seria a chácara destinada a hospedar o imperador D. Pedro II por ocasião da inauguração da rodovia União Indústria em 1861. Porém, o Monarca só conheceu o castelo em 1869, na sua segunda visita, pois este não ficou pronto na época prevista. A casa de campo do comendador era composta ainda por mais três outras casas, ocupadas atualmente pela sede da Quarta Região Militar.

O projeto foi encomendado ao arquiteto alemão Carlos Augusto Gambs, chefe da equipe de engenheiros e arquitetos da Companhia União Indústria, que planejou um castelo totalmente em alvenaria e tijolos. O projeto paisagístico do parque e dos jardins é atribuído ao francês Auguste Marie Francisque Glaziou, que traçou também os jardins da Quinta da Boa Vista no Rio de Janeiro e do palácio Imperial de Petrópolis.

O castelo e o parque hoje são conhecidos como Museu Mariano Procópio. Começaram a se tornar patrimônio de Juiz de Fora por iniciativa de Alfredo Ferreira Lage, que é filho do comendador Mariano. O Museu possui um acervo com peças artísticas, históricas, e científicas, transformado em museu doado à cidade em 1936 e tombado pelo patrimônio municipal na década de 1980. O museu reúne um acervo de cerca de 45 mil obras, sendo a maioria peças do Período Imperial.

Até poucos anos atrás o Museu Mariano Procópio se encontrava em péssimas condições externas(parque) e internas (castelo). Os animais do parque estavam maltratados, muitas pessoas estavam alimentando-os inadequadamente, os macacos atacavam as pessoas, as gaiolas estavam constantemente mal cheirosas. A infra-estrutura estava precária e os equipamentos precisavam de manutenção. $O$ museu estava "abandonado", com muitas goteiras. O acervo estava a cada dia mais danificado. Inclusive não estava mais sendo aberto para visitação. E havia boatos que as peças seriam mandadas para o Museu Imperial em Petrópolis, devido às más condições em que se encontravam.Além disso durante a noite o espaço estava servindo para refúgios de bandidos, local para prostituição, e uso de drogas.

Mas em 2006 fecharam os portões e taparam toda a frente do Museu. Seria 0 inicio de uma revitalização. Dois anos após o fechamento dos portões foi anunciada a reinauguração parcial do parque. A área verde que se situa no centro de Juiz de Fora 
e apresenta características que rememoram sua originalidade do século, foram restaurados e adequados para melhores condições de visitação, ocorreram melhorias das condições de infra-estrutura básica e de apoio ao turista no local. Posteriormente, no principio de 2009 foi anunciada a restauração da parte histórica do museu. A notícia foi dada após Douglas Fazolato, assumir o cargo de diretor superintendente do MAPRO (Museu Mariano Procópio).

\subsubsection{Usina de Marmelos}

A Usina de Marmelos foi a primeira grande usina hidrelétrica da América do Sul, inaugurada em Juiz de Fora, Minas Gerais, no ano de 1889. Foi idealizada pelo industrial Bernardo Mascarenhas, fundador da Companhia Mineira de Eletricidade em 1888.

O objetivo da construção da usina era: atender às indústrias de tecidos do empresário e fornecer eletricidade à iluminação pública da cidade, que até então era alimentada a gás.

A Usina localiza-se no Rio Paraibuna, às margens da estrada União Indústria. O pioneirismo garantiu a Juiz de Fora o título de "Manchester Mineira". A crescente demanda por energia levou à expansão da usina, que atualmente conta com uma potência instalada de $4 \mathrm{MW}$, sendo portanto uma $\mathrm{PCH}$ ( Pequena Central Hidrelétrica). Em 1980, a Usina de Marmelos passa a pertencer à CEMIG, e em 1983 é tombada pelo patrimônio municipal de Juiz de Fora e transformada em espaço destinado à cultura. Foi instalado na edificação da usina o Museu de Marmelos Zero, que desde 2000 é administrado pela Universidade Federal de Juiz de Fora.

\subsubsection{Rua Halfeld}

Segundo Neves(1998), a história da rua Halfeld começa por volta de 1853. Seu nome naquela época era rua da Califórnia. Ela foi aberta em comemoração à elevação da Vila de Santo Antônio à categoria de cidade. Era uma rua central que atraiu as novidades da época. Em 1878 já era macadamizada (sistema de calçamento moderno da época), mas mantinha suas construções precárias, que por fim com o tempo não resistiram. Em 1881, era uma das poucas ruas servida por bondes. Em 1884, o tráfego de muitas carruagens preocupava. Em 1889 passou a contar com iluminação elétrica. 
No final do século XIX até meados de 1930, o perfil urbano da rua Halfeld era o de uma via formosa com construções marcadas por uma preocupação estética, cheia de adornos que contribuíram para dar leveza e encanto às ruas. Eram prédios que ostentavam belas sacadas de ferro trabalhado, com numerosas e amplas janelas.

Dias (2000) afirma que, "a preocupação era construir fachadas bonitas e feitas para serem apreciadas - e de onde também se podia acompanhar o movimento lá fora. A rua Halfeld é considerada o coração da cidade. É uma reta comprida que começa na encosta do Morro do Imperador e atravessa o rio Paraibuna, nasceu para tornar-se ponto de encontro e lugar onde tudo acontece. Estes relatos são pessoas que viveram a juventude em Juiz de Fora na década de $30 . "$

Por lá já passaram bondes e carruagens. No passado era lá que muitas moças e rapazes iniciavam seus romances. E no carnaval, havia marchinhas e batalhas de confete. Era no mesmo lugar também que aconteciam manifestações políticas, e onde acontecia e acontece até os tempos atuais encontros de grupos de pessoas jogando conversa fora.

Mas os tempos mudaram e atualmente os vestígios estão entre novas construções. Atualmente, tornou-se um calçadão, e ainda tem em sua característica ser um ponto de encontro. Mas é tomado de poluição sonora e visual.

A rua Halfeld foi vítima de sua própria valorização como principal via comercial e posteriormente residencial. Muitas das antigas construções foram demolidas dando origem a edifícios enormes com novos padrões arquitetônicos, abandonando a ornamentação como demonstra o casarão construído no início do século XX (figura 2) e priorizando a funcionalidade. Na parte baixa da rua, trecho entre a avenida Getúlio Vargas e a Praça João Penido (figura 3), ainda possui exemplares da antiga paisagem arquitetônica. Em ambas figuras é possível reparar que o entorno está repleto de poluição visual e a presença de camelôs. Além disto é o local possui alto índice de criminalidade. 


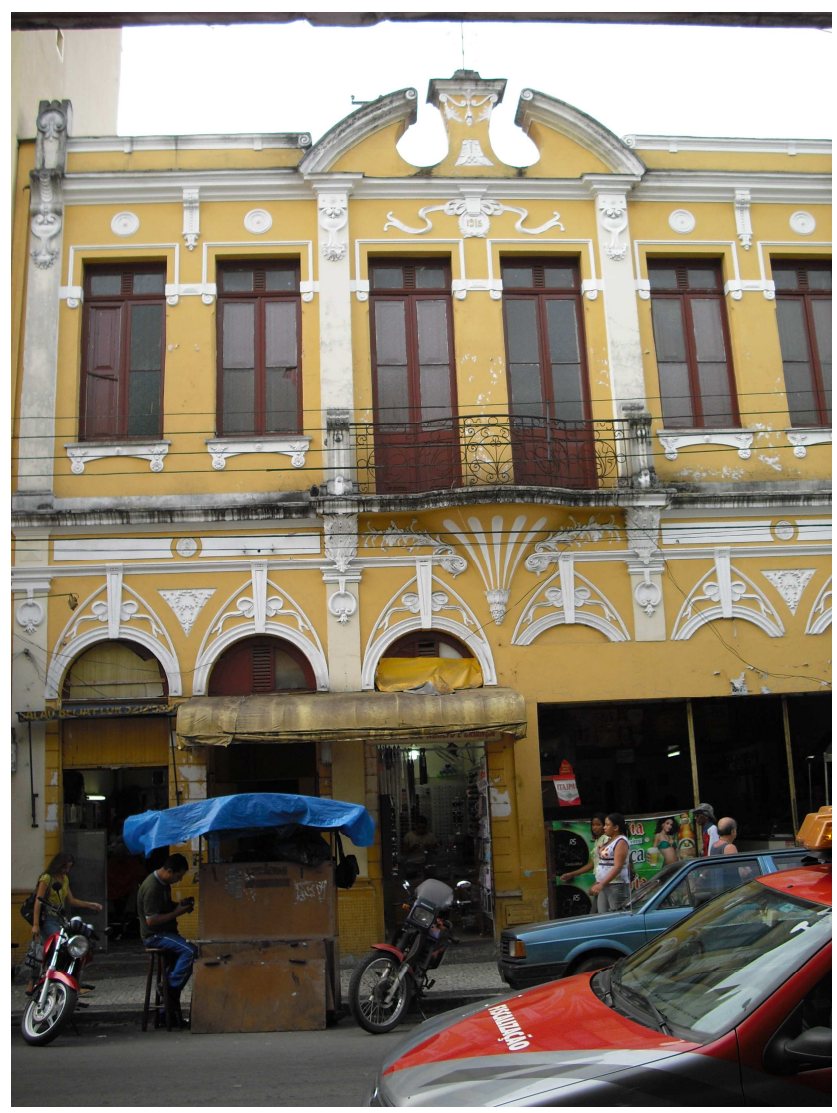

Figura 2:Construção na Rua Halfeld do início do Século XX. Foto: Feito pela autora

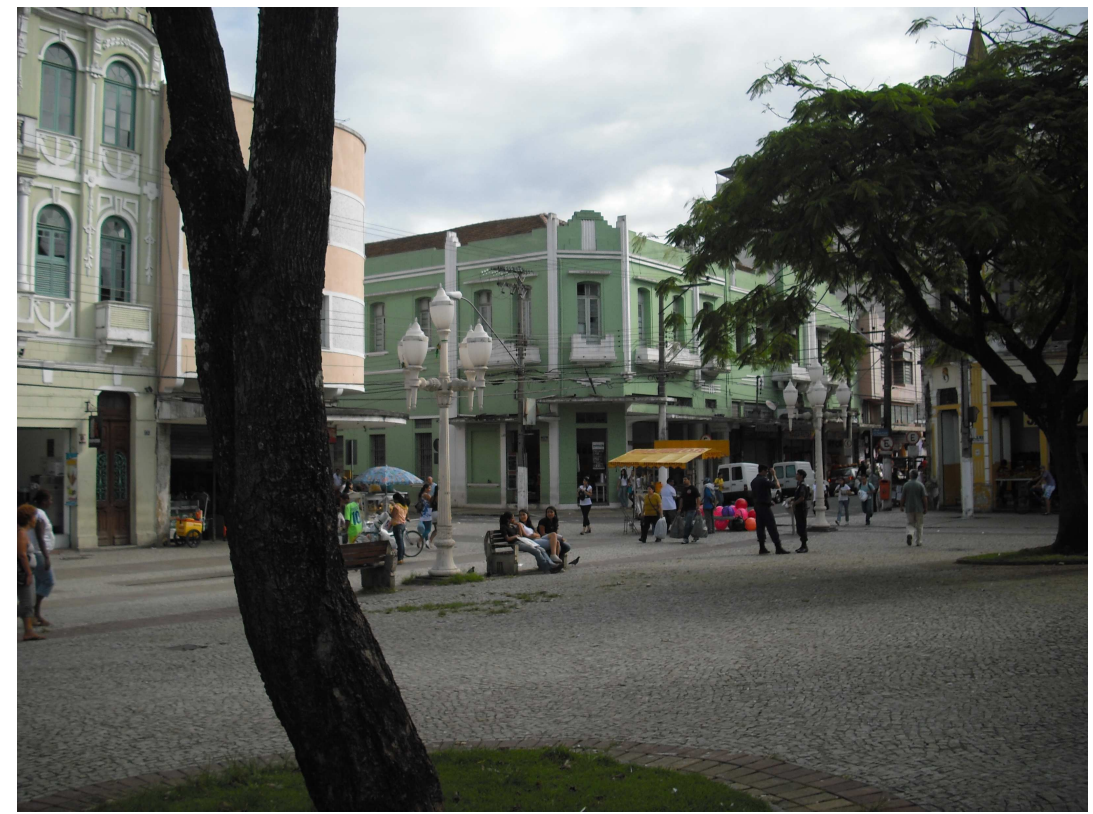

Figura 3:Início da Rua Halfeld "Praça da Estação" Foto: Feito pela autora 


\subsubsection{Parque Halfeld}

Segundo Dias(2000) o local é considerado como o primeiro logradouro público de Juiz de Fora o terreno foi adquirido pela câmara municipal em 1854. No ano antecedente haviam sido abertas duas ruas próximas ao terreno: rua Califórnia e rua Câmara. Atualmente as mesmas são chamadas de rua Halfeld e Avenida Rio Branco e justamente no cruzamento destas estava situada a câmara municipal.

Esteves (1915, p.111) descreve o lugar: "Apesar de ser chamado largo, o lugar não tinha características bucólicas de um jardim, não havia calçamento, e a área era bastante pantanosa. Naquela época o local era utilizado para instalações de "circo de cavalinhos, touradas e cavalhadas."

Dias (2000), relata também que em 1880, o arquiteto Miguel Antônio Lallemanté encarregado de elaborar a planta do ajardinamento do largo Municipal. Mas o resultado desagrada aos vereadores. Em vistoria ao local constatam que as obras realizadas não estavam de acordo com a planta. Vinte anos mais tarde, em 1901, o largo municipal foi completamente remodelado por Francisco Mariano Halfeld, filho do engenheiro Fernando Halfeld - que custeou todas as despesas das obras executadas pela Companhia Pantaleone Arcuri. A companhia levantou canteiros, construiu lagos, pontes, e casas rústicas além de um pavilhão central. Após a remodelagem em 1902 o largo passa a se chamar Praça Coronel Halfeld. Mas mudanças sucessivas ocorreram nas décadas de 50, 60,e 80 e a concepção paisagística mudou, então passou a se chamar Parque Halfeld, como até hoje é conhecido.

Apesar de muitas mudanças e da descaracterização do parque o que muitas pessoas dizem ser a perda de identidade, o parque conserva do projeto original apenas seus lagos e suas pontes. Mas mesmo assim foi tombado pelo patrimônio municipal em 29 de dezembro de 1989.

\subsubsection{Museu Ferroviário}

A edificação data de 1928, foi erguida seguindo um modelo neoclássico, onde predominam a simetria compositiva e a sobriedade sendo o volume compacto decorado com ranhuras corridas. (DIAS;2000. p.18) 
A sede da antiga Estrada de Ferro Leopoldina, que hoje abriga o Museu Ferroviário de Juiz de Fora, foi construída para substituir a primeira estação, inaugurada no final do século XIX. Edificado em padrões ecléticos, o prédio apresenta em sua fachada uma prevalência de elementos da arquitetura clássica, como frontões triangulares, pilastras no pavimento superior; janelas e portas do térreo encimadas por bandeiras em arco pleno. A técnica construtiva empregada é a alvenaria de tijolos maciços, coberto com telhas francesas.

No projeto original, o pavimento térreo abrigava a sala do agente e do telégrafo, o armazém, os sanitários, a sala das senhoras e o bar. Já no andar superior havia a casa do agente da estação. No entanto, ao longo dos anos, a construção sofreu várias reformas que modificaram a construção original.

No ano de 1977, o prédio da Estrada de ferro Leopoldina ganhou dois corpos laterais no pavimento superior, onde localizavam-se os terraços da casa do agente. $\mathrm{Na}$ escada do pavimento superior, onde localizavam-se os terraços da casa do agente. Na escada para o pavimento superior foi eliminada, uma nova escada foi construída no hall principal e as divisões internas foram totalmente reformuladas. Uma nova obra de adaptação foi implementada em 1985, quando o prédio passou a abrigar o Núcleo Histórico Ferroviário.

No térreo foram ambientadas as salas de exposição do acervo ferroviário, enquanto no pavimento superior foram instalados o centro de documentação, a Sala de exposição Temporária, a Galeria de Arte e a administração do Núcleo. Em 1999, por meio de um convênio celebrado entre a RFFSA e a prefeitura de Juiz de Fora, a Fundação Cultural Alfredo Ferreira Lage - FUNALFA assumiu a administração do espaço que passa a se chamar Museu Ferroviário Juiz de Fora. As diretrizes implantadas são a dinamização das ações de natureza turístico - cultural e educacional, particularmente aquelas relacionadas com preservação, valorização e difusão do patrimônio, da memória e das tradições ferroviárias.

Dentro desse processo de revitalização, como troca do piso, nova pintura, conservação e restauração de peças, reforma do anfiteatro, além de ganhar telas de proteção e jardins. O acervo foi reorganizado e agora está disposto de forma didática, em vitrines, painéis e ambientes cenográficos, réplicas de locomotivas importantes como a Leopoldina( Figura 4). O núcleo histórico ferroviário foi inaugurado em 1985, 
teve seu espaço interno reformulado em 2003 e passou a ser museu ferroviário. Possuindo hoje, um acervo de 300 peças aproximadamente.

Em uma entrevista com a jornalista Lívia Maia que é responsável pela produção cultural do Museu Ferroviário a funcionária relata que o museu recebe maior número de visitantes de fora da cidade que de juizforanos. Ela relata que cariocas e paulistas possuem muitas curiosidades com relação ao trem."Muitas vezes essas pessoas que vem à Juiz de Fora para tratar de negócios e no hotel fica sabendo do Museu e vem, porque quem não é mineiro parece ter muito mais curiosidade e muito mais carinho com o trem ( trem de ferro), muito mais que o mineiro as vezes."

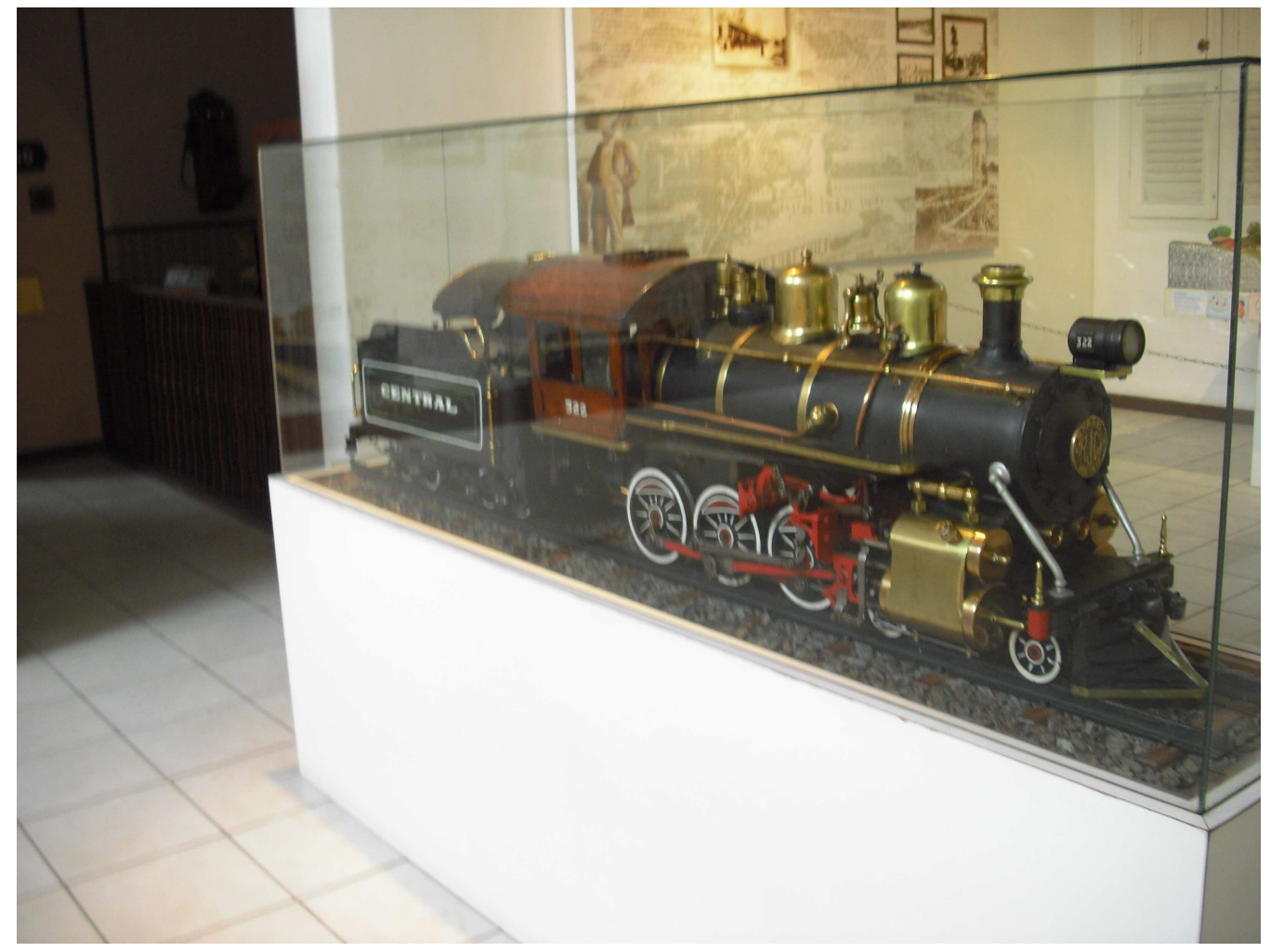

Figura 4:Réplica Locomotiva foto: Feito pela autora

Lívia afirma também que muitos moradores locais sequer sabem da existência do museu. E que existe uma parceria com escolas públicas, o museu então vai até as escolas, fazem a divulgação através de atividades lúdicas e com objetivo de instigar a curiosidade dos estudantes. 
Após este primeiro contato a escola leva os alunos ao museu e lá os adolescentes assistem a um documentário e as crianças assistem a um teatro de sombras, ambos procuram provocar interesse no público com relação à importância histórica do Trem.

\subsubsection{Morro do Imperador}

O morro do imperador é um monumento natural que, situado na parte oeste da cidade não poderia deixar de ser uma atração turística.(DIAS,2000,p.24)

Em Esteves(1915) consta que em 1861, o Imperador Dom Pedro II presente em Juiz de Fora em virtude da inauguração da estrada União Industria, subiu ao topo da colina para tentar visualizar algum efeito relacionado a um cometa que naquele a terra atravessara sua cauda. Dom Pedro procurava qualquer coloração na atmosfera que pudesse ter resultado dessa passagem. Em homenagem acabou conhecido como morro do Imperador. Mas também é conhecido como morro do Cristo.

Na passagem do século Francisco Batista de Oliveira idealizou a elevação de um cruzeiro, e em 1906 foi construído um monumento do Cristo Redentor simbolizando a morte do idealizador do cruzeiro. A Imagem do Cristo mede três metros de altura e tem origem francesa. O monumento na integra mede 25 metros.

O local é utilizado como área de lazer desde de 1886 quando João Alves Brito oferecia terrenos de sua propriedade no alto do morro para construção de local de recreação.

O Morro do Cristo foi tombado pelo decreto no 4312, de 24 de maio de 1990. A municipalidade considerou o valor histórico, cultural, paisagístico, e ambiental do Morro, uma "barreira natural que orientou a expansão urbana de Juiz de Fora". Sendo importante marco referencial em Juiz de Fora.

\subsubsection{Catedral Metropolitana}

Registros em Esteves (1915) relatam que a Catedral Metropolitana foi a terceira capela a ser construída na cidade (figura 5). Tendo a autorização para iniciar a obra em 28 de março de 1844, pelo presidente da província, que deu licença aos moradores do Juiz de Fora para erguerem um templo dedicado a Santo Antônio. O Bispo de Mariana, Dom Antônio, assinou a autorização em dezembro daquele ano. A construção foi concluída em 1847 e era ampla, mas sem torres. 


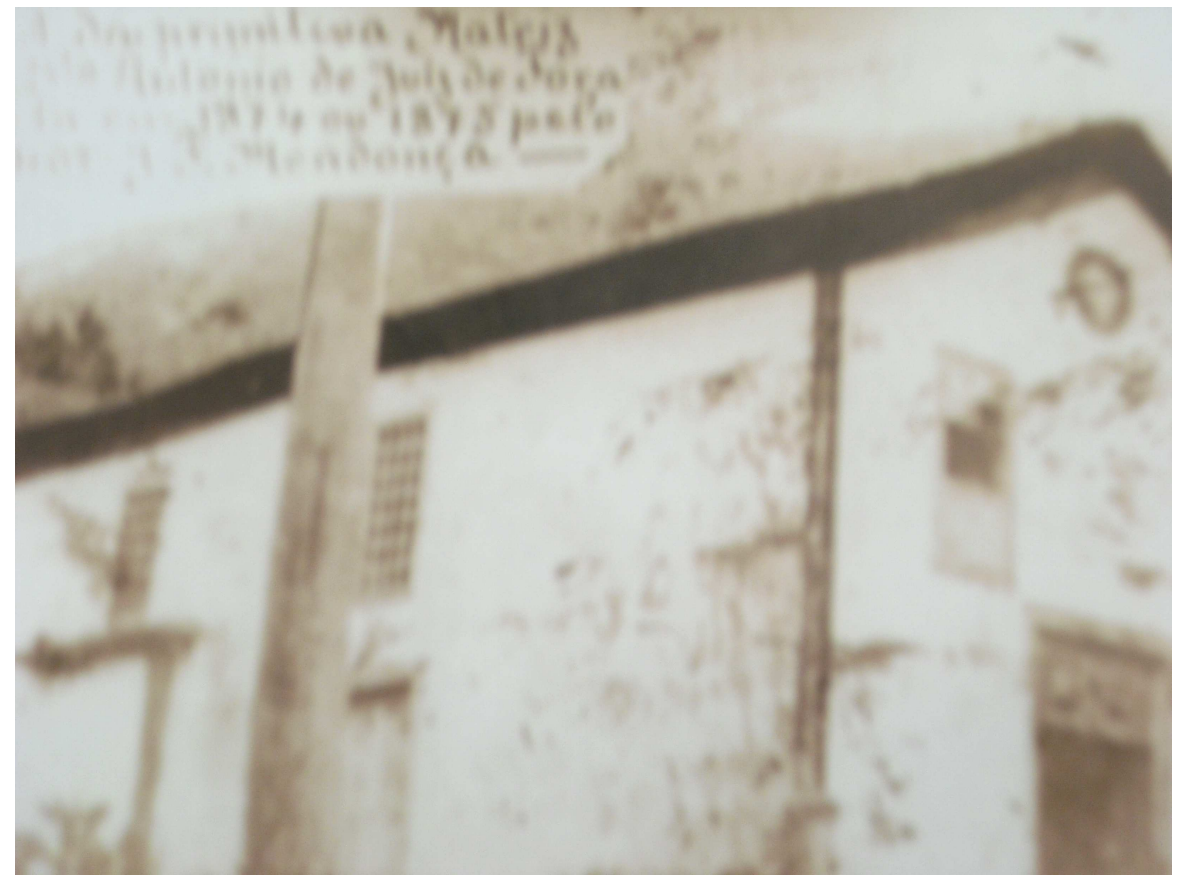

Figura 5: Terceira capela.

Fonte: Esteves (1915)

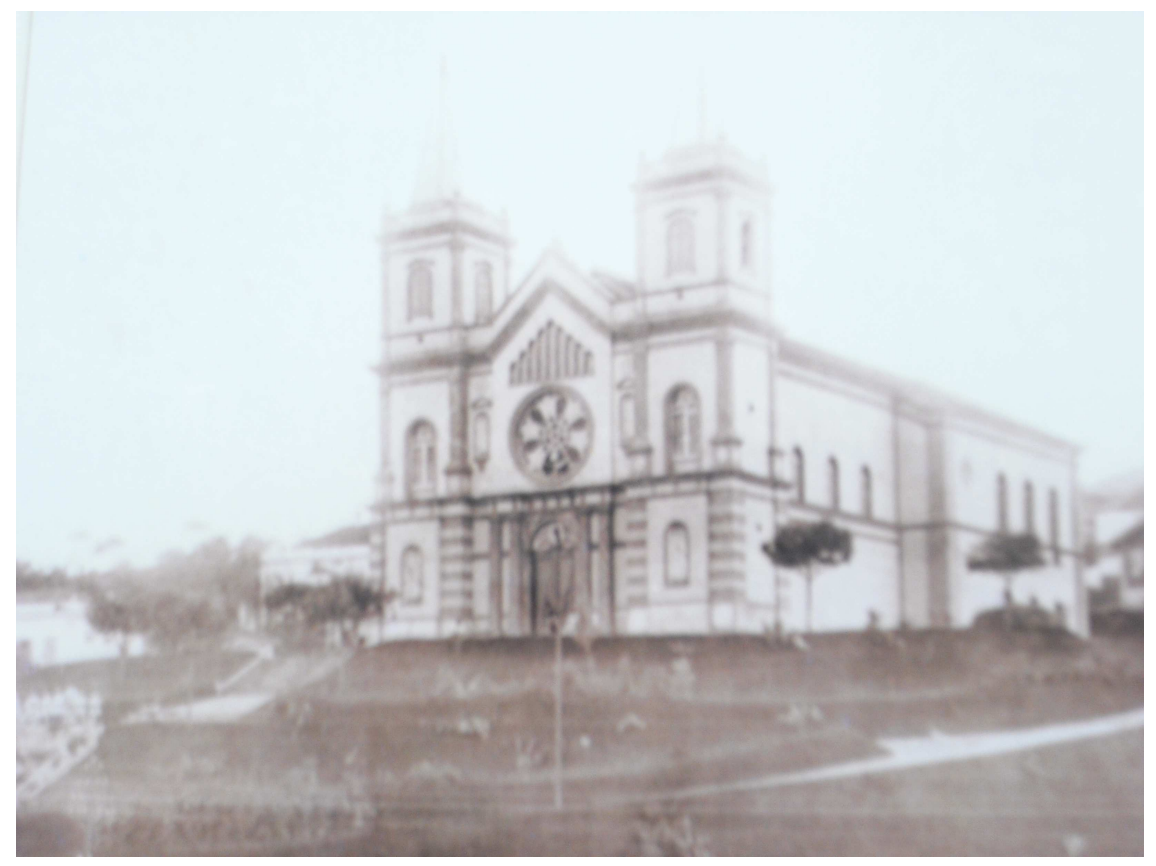

Figura 6:Igreja Matriz, atual Catedral de Juiz de Fora Fonte:Esteves (1915)

Apesar de grande, a capela rapidamente, mostrou-se sem capacidade para abrigar os fiés. Foi preciso construir uma igreja maior atrás do prédio original. O novo projeto era de uma igreja com duas torres e um amplo jardim. Quando o arraial foi elevado à categoria de Vila, em 31 de maio de 1850, com o nome de Santo Antônio do Paraibuna, a capela passou à condição de matriz. 


\subsubsection{Festa Alemã}

Anualmente acontece na cidade Deutches Fest (Festa Alemã) do bairro borboleta. Durante os festejos alemães é possível encontrar culinária típica alemã, músicas e dança típicas. Mas nos últimos anos a festa vem perdendo suas características iniciais e que motivaram sua existência. Pois além dos pratos típico alemães e barracas com apresentação de traços culturais Germânicos a Festa vem se transformando em uma miscelânea cultural pois abre espaço para orquestra sinfônica, músicas e danças flamencas, árabes, italianas e portuguesas. O objetivo do festejo dos descendentes de colonos alemães que pertencem àquela comunidade se distorceu. E nos dias de hoje a festa procura agradar ao público, ao invés de recordar a cultura da comunidade alemã.

\subsubsection{Museu Crédito Real}

O Banco Crédito Real é a referência mais importante no processo de evolução do sistema financeiro na região da Zona da Mata mineira. Entre seus fundadores a maioria era constituída por fazendeiros com títulos de nobreza, exemplos são Barão de Monte Mário e de Santa Helena. Também se destacaram o industrial Bernardo Mascarenhas e o comerciante Francisco Batista de Oliveira.

O motivo de sua criação foi que no final do século XIX Juiz de Fora atraía empreendimentos industriais por dispor de mão-de-obra qualificada. Afinal os imigrantes alemães que vieram para a construção da estrada União Indústria, já haviam concluído os serviços e estavam se dedicando à implantação de pequenas fábricas. Além disto a cidade se transformara em escoadouro da produção cafeeira da região. Os dois fatores movimentavam a economia e geravam grande acúmulo de capitais. Juiz de Fora era então considerada um grande cenário para os negócios, tornado-se necessário a organização de um sistema financeiro local.

O Banco de Crédito Real (Figura 7) iniciou suas atividades em 5 de setembro de 1889, e foi o único banco de Minas Gerais durante muitos anos.

O belo prédio do Banco de Crédito Real, na rua Halfeld, é um dos exemplares arquitetônicos dos anos 20 na cidade, representante da industrialização que marca Juiz de Fora e a distingue no contexto arquitetônico mineiro.De estilo neoclássico, o edifício construído em 1929 pela Companhia Pantaleone Arcuri remete a conceitos como racionalidade, ordem, solidez e equilíbrio, bem apropriados a uma instituição bancária. Os dois pavimentos superiores do edifício foram acrescentados posteriormente. $O$ 
prédio, o museu, e o arquivo histórico do banco são tombados pelo patrimônio histórico municipal. (DIAS,2000,p.57)

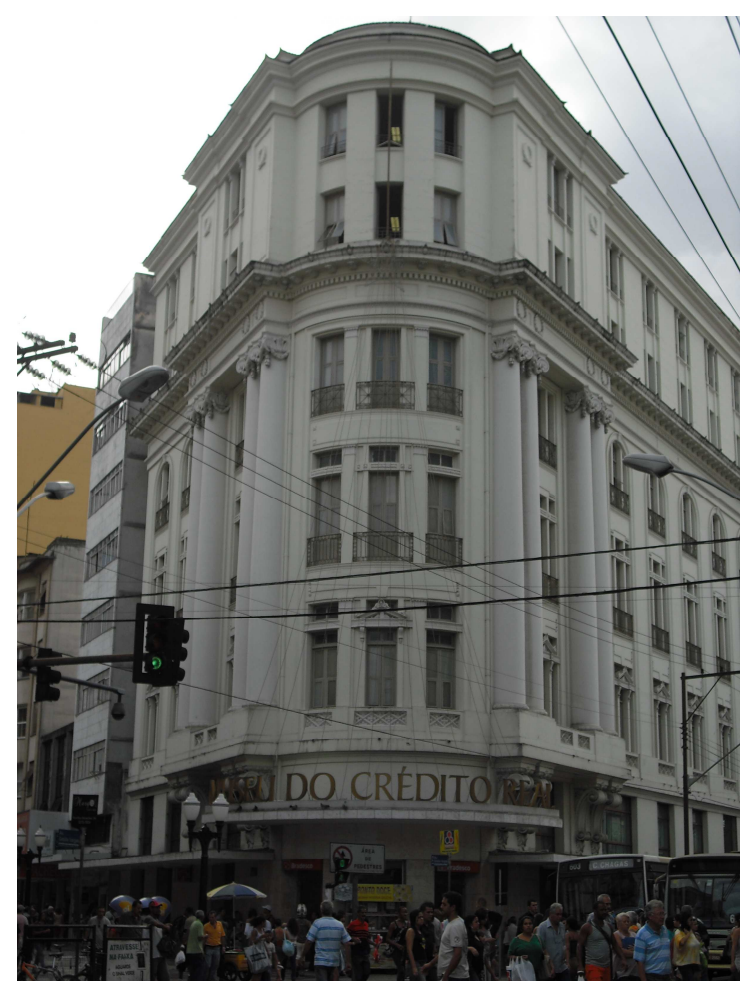

Figura 7:Museu do Crédito Real Fonte: Feito pela autora

\subsubsection{Fazendas históricas de Juiz de Fora}

Esteves (1915) esclarece que a história das fazendas da região da Zona da Mata está relacionada com a distribuição das Sesmarias ao longo do Caminho Novo nas primeiras décadas do século XVIII. Muitas das Sesmarias deram origem as fazendas, pois foram divididas ao longo do tempo.Quando foram divididas as fazendas tinham como objetivo o abastecimento interno. Milho, mandioca, e outros itens básicos a subsistência que mais tarde passaram a garantir o sustento dos viajantes que se dirigiam para áreas de mineração ou que de lá voltavam em direção ao litoral.Juiz de Fora passou a ser ponto de parada destes.

Em Oliveira,1999 consta que A partir do século XIX estas fazendas passaram a ser produtoras de café, fator este que movimentou consideravelmente a economia da região uma vez que o excedente de capitais vindos da extração aurífera precisava ser aplicado em novos empreendimentos. 
Na segunda metade do século XIX, Juiz de Fora se destacou como principal centro produtor de café de Minas Gerais e concentrou a maior população escrava da província mineira. Santo Antônio do Paraibuna, que mais tarde passou a ser chamado de Juiz de Fora, chegou a ter uma média de 100 escravos por fazenda, isso caracterizava uma grande população no campo.

A Zona da Mata Mineira, mais especificamente Juiz de Fora(principal cidade da região), desenvolveu-se após ter sido um grande polo cafeeiro no século XIX, em conseqüência disto possui atualmente importantes que surgiram neste período da história de Juiz de Fora.

Algumas destas fazendas ainda existem, são elas:

a) Fazenda Palmital: Não foi encontrado registro histórico ou documental, então não há como saber a data precisa da construção. No entanto um dos atuais proprietários que diz ser neto do antigo dono, relata que a fazenda foi construída no fim do século XIX. A fachada da casa (sede da fazenda) permanece mas seu interior já foi bastante modificado. Outra mudança feita no estilo da fazenda foi o telhado. $O$ original era de pau a pique e atualmente é de telha colonial. Localiza-se no distrito de Rosário de Minas. Não há sinalização indicando o nome da Fazenda nas vias de acesso, nem na sua entrada. Os proprietários parecem não saber da importância histórica da fazenda para a região.

b) Fazenda Vista alegre: A fazenda que também da aparenta ser do período cafeeiro no andar de baixo de sua casa (sede) que era de chão batido, correntes e algumas algemas de ferro, que eram usadas para acorrentar e algemar os escravos. As paredes da antiga senzala guardam resquícios da antiga construção de pau a pique e tetos de treliças.

c) Fazenda São Mateus: é considerada em Juiz de Fora o símbolo do período cafeeiro. Fundada na primeira década do século XVIII por Matias Barbosa da Silva, através de uma doação de Sesmaria concedida por D. Fernando Mascarenhas de Lancastre ( Governador da Capitania do sul do Brasil), e confirmada por EI - Rei D. José I em 21 de julho de 1766. (GOMES, 1933 p.32) 
Localiza-se a $12 \mathrm{Km}$ do centro de Juiz de Fora, caminho para Rio Preto, possui fácil acesso( asfalto até a porta ). E é considerada um modelo de preservação. O atual proprietário procurou não "agredir" a construção antiga com reformas. Até os móveis e instrumentos antigos são guardados. A fazenda participou de parte importante da história do país ao hospedar os inconfidentes quanto estes eram levados à côrte.

Atualmente a fazenda é auto-sustentável, possui atividades como produção de leite, cultura de milho, soja e café, pecuária de corte e outros.

A fazenda é aberta ocasionalmente no período de Férias para visitação. proprietário aluga para alguns hotéis da região.

d) Fazenda Cachoeirinha: Fazenda também com características do período cafeeiro escravista. O proprietário não tem interesse em abri-la para visitação e nem mesmo tem interesse em preservar suas características históricas.

e) Fazenda Ribeirão das Rosas: a fazenda também histórica, tombada pelo patrimônio municipal encontra-se em péssimo estado de conservação. Relatos do funcionário Eduardo Millione confirmam que além da falta de cuidado, o desrespeito à capacidade de carga contribuíram para a aumentar os danos. Segundo o processo de tombamento a rusticidade da fazenda é característica do século XVIII, época em que nem o conforto e nem a estética eram preocupações na construção de um imóvel. A fazenda atualmente corre risco de desmoronar em períodos chuvosos.

f) Fazenda da Tapera: muito importante no período da mineração por possuir sua história relaciona à abertura do Caminho Novo. Pois a abertura deste criou a necessidade de maior patrulhamento e fiscalização da Coroa que precisava evitar contrabando de ouro. Tais acontecimentos datam 1711 e podem ser verificados em uma Carta de Manoel de Araujo:

(...) Faço saber aos que esta minha Carta patente virem que por quanto se faz muito conveniente haver no Caminho Novo que vai para o Rio de Janeiro, um cabo de todos aqueles moradores da Borda do Campo, até a passagem do Paraibuna que possa que possa conservá-los, e crimes que suceda haver quem os prenda com jurisdição e os remeta a estas minas para serem castigados por mim e pela justiça; e atendendo a capacidade, e merecimento de Manoel Araújo, morador, e dos primeiros povoadores, do dito 
caminho, e referido distrito, sempre com bom procedimento e prontidão no adjutório dos Correios, e diligências que sucedem passar parte do seu sítio em serviço de Sua Majestade e haver-se da mesma sorte na ocasião em que veio o Capitão mor Leonel da Gama com um corpo de gente a trazer munições a estas minas, e socorrer o Rio das Mortes, quando chegarão aquele arraial os paulistas em som de guerra, dando - Ihe mantimentos, e tudo 0 que Ihe foi necessário em tempo era que havia falta deles; e por esperar dele se haverá com o mesmo zelo em tudo o que se the encarregar e for da boa conservação daqueles moradores, e melhor utilidade dos passageiros, hei por bem eleger e promover(...) ao dito Manoel de Araújo no posto de Capitão da ordenança e moradores do Distrito do Caminho Novo da borda do Campo, até o Rio Paraibuna para que os conserve em paz, e com respeito, e obediência que em razão do dito posto lhe é permitido; o respeito, e obediência que em razão do dito posto the é permitido; o qual exercitará enquanto eu o houver por bem; e com ele gozará de todas as honras, privilégios e isenções que lhes são permitidas. (ESTEVES, 1915 p.32)

Neves(2004) relata que em 1708, Tomé Corrêa Vasquez, recebeu uma sesmaria, onde hoje se localizam os bairros Santa Terezinha, Bandeirantes e Granjas Betânia. Antes da legalização da concessão da Sesmaria, em torno de 1700, Tomé Corrêa havia contratado Pedro Durval para construção de uma casa, onde aquele residiu até sua morte. Esta casa é a mais antiga repartição pública de Juiz de Fora e de toda essa região do estado, residência essa onde Tomé Corrêa Vasquez desempenhou a função de Alcaide-Mor, encarregado de arrecadar e fiscalizar a renda devida à fazenda Pública. Após sua morte, a sede da casa, denominada Fazenda do Alcaide-Mor, da Tapera ou Alcaidemoria foi adquirida pela família Vidal que nela residiude 1756 a 1764, depois pelos Tostes até 1879, e finalmente pela família Tristão em 1883. Posteriormente a fazenda foi doada em testamento para a Santa Casa de Misericórdia de Juiz de Fora.

A região possuía outras fazendas cafeeiras, tais como: a Fazenda Salvaterra, Fazenda Santa Clara, e Fazenda Mundo novo entre outras. Mas assim como as demais o descaso com as questões históricas é predominante. A fazenda Salvaterra foi demolida, e as outras duas citadas, existem mas estão completamente descaracterizadas. 


\subsection{Dados estatísticos a respeito do turismo em Juiz de Fora.}

Durante a visita à Prefeitura Municipal de Juiz de Fora, o Secretário de Transporte Márcio Bastos relatou à pesquisadora que a recém criada secretaria de Turismo, Indústria e Comércio de Juiz de Fora já havia sido extinta. Passando então suas responsabilidades referentes ao turismo para o chamado Núcleo de Turismo cuja responsável era a estagiária Thais de Oliveira Lima.

A estudante confirmou a extinção da Secretaria de Comércio, Indústria e Turismo, e afirmou que existiu uma proposta de realização de um novo inventário turístico na gestão do antigo prefeito Alberto Bejani, e que houve o levantamento de dados, porém a falta de preparo e de capacitação dos pesquisadores que trabalharam na coleta de dados contribuiu para a estagnação do processo de inventário, devido a falta de confiabilidade dos dados levantados.

Segundo o senhor Márcio Bastos(Secretário de Transportes) o estudo mais recente com dados confiáveis seria o "Plano Estratégico Setorial do Turismo de Juiz de Fora" proposto em 2004 durante a segunda gestão municipal consecutiva de Tarcísio Delgado. Neste momento da pesquisa foi possível perceber a falta de continuidade dos projetos elaborados em diferentes planos de governo, pois os dados existentes no plano estratégico setorial de Turismo não foram utilizados na gestão passada e quiçá na atual gestão.

A partir dos dados inventariados para a realização do Plano Estratégico Setorial do Turismo foi possível acesso às informações de relevante aspecto para a realização deste trabalho.

O perfil do turista de Juiz de Fora foi determinado após o levantamento de informações, com aplicação de questionário estruturado sob a forma de entrevista direta. No período de 10 a 22 de abril de 2002, foram realizadas 955 entrevistas em hotéis, restaurantes, eventos, atrativos turísticos, comércio, rodoviária e aeroporto.

Consta em JUIZ DE FORA (2004) que "Os resultados mostraram um equilíbrio na presença de Homens e Mulheres entre os visitantes, uma maioria com idade acima de 31 anos, formação de nível superior, e renda mensal própria acima de $\mathrm{R} \$ 801,00$, residentes em estado da região sudeste, principalmente em Minas Gerais. O motivo principal das viagens é a realização de negócios em Juiz de Fora e o meio de transporte utilizado é o ônibus de linha regular. Viajam, em geral, sozinhos passam 
mais de um dia na cidade e hospedam-se em hotéis ou casa de parentes e amigos e fazem refeições em restaurantes."

A figura 7 é um gráfico referente ao tempo de permanência do turista ou visitante, e a figura 8 é o gráfico mencionando os locais visitados pelo turista, estavam presentes no Plano e foram utilizados em nosso estudo. Pois são dados importantes para a criação de objetivos em um planejamento turístico.

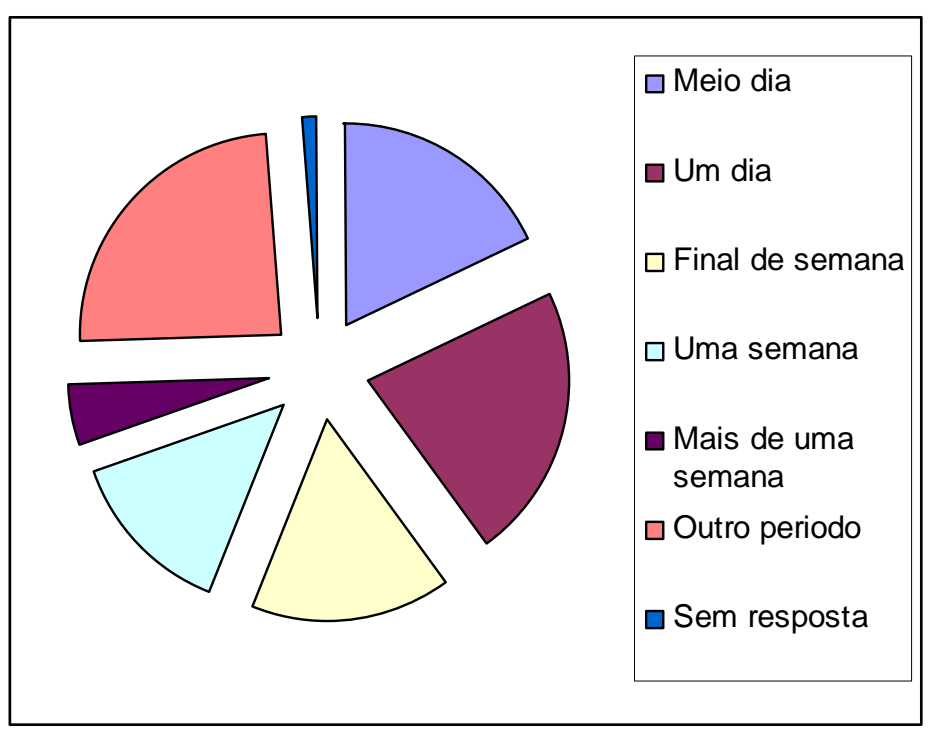

Figura 8 : Tempo de permanência do turista em Juiz de Fora

Fonte: Plano estratégico setorial de turismo de Juiz de Fora 2004

O gráfico que representa o tempo de permanência do turista em Juiz de Fora mostrou como resultados que: $17,6 \%$ dos turistas passaram apenas meio dia na cidade, 21,3 \% passaram um dia inteiro na cidade, $15,5 \%$ passaram um final de semana, 13,3\% passaram uma semana inteira, 4,8\% passaram mais de uma semana, $2,7 \%$ passaram um mês, $23,8 \%$ e $1 \%$ passaram outro período ou não responderam respectivamente.

O gráfico apresentado na figura 7 demonstra que a maioria dos turistas que vêm para Juiz de Fora e permanecem pouco tempo na cidade. $E$ analisando conjuntamente os gráficos das figuras 7 e 8 , é possível perceber que os turistas que visitam Juiz de Fora não permanecem mais tempo na cidade devido à falta de informação a respeito de opções de lazer e locais para serem visitados. 


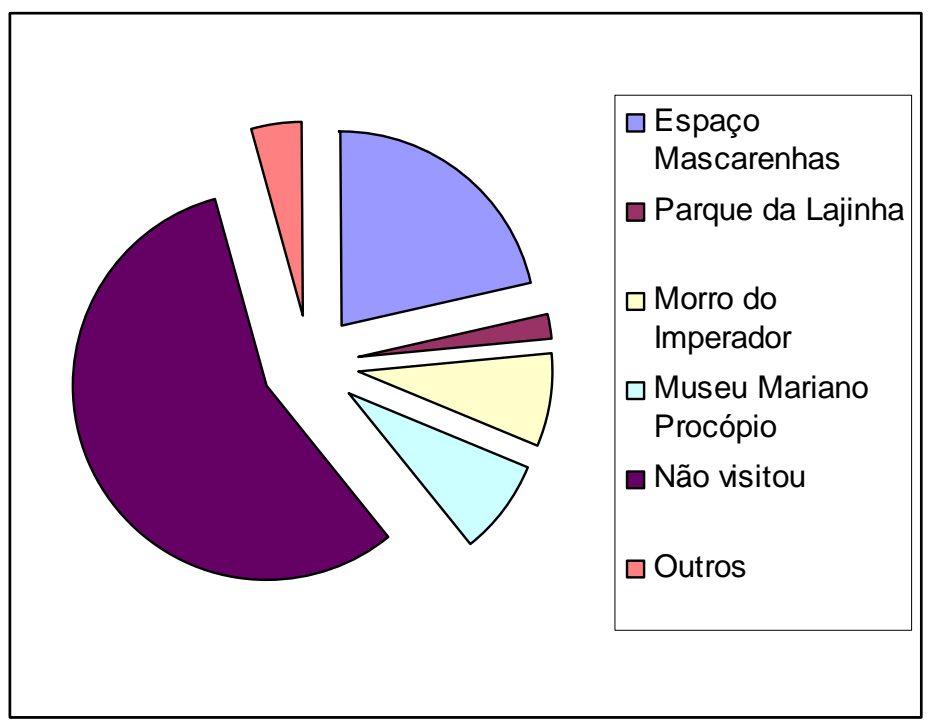

Figura 9: Local visitado

Fonte: Plano estratégico setorial de turismo de Juiz de Fora 2004

No gráfico que mostra os locais visitados pelos turistas é retrata que $21,7 \%$ das pessoas que visitaram Juiz de Fora estiveram no Espaço Mascarenhas, 2,0\% foram ao parque da lajinha, 7,6\% estiveram no Morro do Imperador, 8,0\% visitaram o Museu Mariano Procópio, 4,3\% visitou outros lugares e 56,4 \% não visitou lugar algum.

Mais da metade dos turistas não visitou nenhum atrativo turístico da cidade, a pesquisadora acredita que o baixo índice de visitação e não visitação dos atrativos ocorra pela falta de informação tanto do turista quanto do morador da cidade. Percebeu-se também falta de interesse por parte do Poder Público Municipal em incentivar a promoção do turismo em Juiz de Fora.

O estudo feito durante a elaboração do plano estratégico setorial de turismo revela que Juiz de Fora já possui características relevantes, Mas que precisam ser potencializadas. Surgem como desafios a serem vencidos a sensibilização e o envolvimento da comunidade com o turismo;o desenvolvimento de produtos turísticos atraentes; a captação de novos turistas, gerando um ciclo vicioso no desperdício de oportunidades e a falsa idéia de que a cidade tem pouco a oferecer em termos de lazer e cultura.

O Patrimônio arquitetônico e histórico de Juiz de Fora merece atenção por representar, com boas condições gerais de preservação, períodos importantes da arquitetura brasileira. No centro da cidade estão localizados bens de interesse turístico, que podem encantar o turista regional e nacional, seja ele 
especializado ou apenas interessado em conhecer testemunhos tão marcantes do passado da cidade. Naturalmente alguns desses monumentos necessitam de um pouco mais de conservação ou restauração, mas o conjunto, com a de uma política de incentivo, baseada nas leis municipais, estaduais e federais, novos projetos de revitalização surgirão para contribuir ainda mais para tornar Juiz de Fora um destino cultural.(JUIZ DE FORA,2004)

\subsection{O inventário turístico de Juiz de Fora}

O inventário turístico foi realizado pela prefeitura de Juiz de Fora durante o mandato de Tarcisio Delgado. Para a elaboração do Inventário Turístico de Juiz de Fora foram aplicados 52 tipos de questionários que incluíram 1500 itens nos diversos setores hotéis, agências de viagens, transportadoras turísticas, serviços de comunicação e de saúde, casas de shows, espaços culturais, instituições históricas e culturais, galerias, bares e restaurantes, entre outros. Após um pré diagnóstico, foram apresentadas temas críticos, são eles: Informação, comunicação e sensibilização, articulação e parcerias, valorização dos Atrativos, captação e promoção de Eventos, Infra - estrutura turística, atendimento, regionalização e oportunidade no comércio.

No mesmo documento foram citados pontos fracos e fortes do turismo em Juiz de Fora e citados na fase do diagnóstico. No presente trabalho, estas pontuações também foram comentadas.

Pontos fortes:

- Sistema de comunicação desenvolvido e de repercussão regional e nacional;

- Educação de qualidade;

- Boa infra estrutura turística: hotéis, serviços de alimentação, agências de viagem, transportadoras turísticas e organizadores de eventos;

- Desenvolvimento de circuitos e produtos regionais, integrando atrativos e valorização das potencialidades, com a elaboração de projetos comuns;

- Influência nos municípios da região;

- $\quad$ Proximidade dos principais centros emissores de turistas;

- Boa infra estrutura de serviços;

- A cidade abriga eventos de tradição nacional e internacional; 
- Presença de manifestações culturais e artesanato local;

- Comércio variado, com peculiaridades;

- Importante patrimônio histórico, artístico e ambiental.

Pontos fracos:

- $\quad$ O Juizforano não considera a cidade atrativa, não prestigia suas atividades e se afasta sempre nos feriados e férias;

- Pouca articulação entre órgãos responsáveis pelo meio ambiente, cultura, comunicação, esportes e turismo;

- $\quad$ Pouca articulação entre empresas do setor;

- Inexistência de uma estrutura pública para o turismo;

- Infra estrutura receptiva insuficiente;

- $\quad$ Baixa qualidade no atendimento ao público;

- Horário de funcionamento do comércio;

- O patrimônio histórico, artístico e cultural não é aproveitado para o turismo;

- $\quad$ O empresariado não participa da valorização dos atrativos;

- Baixa qualificação de mão de obra do setor;

- Deficiente comunicação sobre a cidade.

A análise destes pontos fracos e fortes que constituem o estudo feito para a elaboração do plano estratégico municipal quando trazido para o contexto do turismo histórico cultural de Juiz de Fora como um potencial a se desenvolver precisa ser mais bem esclarecida. O plano expõe, por exemplo, o fato de Juiz de Fora possuir importante patrimônio histórico, artístico e ambiental, fator importantíssimo do desenvolvimento cultural da cidade, mas que se enfraquece quando tratamos de turismo por vários outros fatores mostrados na pesquisa.

O primeiro é que o patrimônio histórico, artístico e cultural não é aproveitado para o turismo. Em segundo lugar se o Juizforano não considera a cidade atrativa, não prestigia suas atividades e se afasta sempre nos feriados e férias. Torna-se mais difícil de causar interesse por um lugar no turista quando os próprios moradores desvalorizam este lugar. Além da falta de informação existente a respeito das características histórico culturais de Juiz de Fora. 
Outro fator crucial para o não crescimento da atividade turística é a ausência de políticas públicas que fomentem a atividade no local. No item abaixo é possível perceber que há pouco interesse da prefeitura na valorização da atividade turística. Além disso o fato de existir pouca articulação entre órgãos responsáveis pelo meio ambiente, cultura, comunicação, esportes e turismo interfere negativamente por não considerar o turismo como uma atividade interdisciplinar uma vez que não constrói ligação entre os setores a ele relacionado.

\subsection{O Governo Municipal e os projetos de incentivo ao turismo cultural}

O Núcleo de turismo da Prefeitura municipal de Juiz de Fora conta apenas com duas estagiárias (estudantes do Turismo) para a realização de suas atividades. Não existe nenhum profissional já graduado envolvido em captação de recursos, ou elaboração de projetos. E as duas estagiárias que lá se encontram acumulam também outras funções referentes à outros departamentos. Assim é possível confirmar a ausência de uma estrutura pública responsável pelo turismo. Diante da situação descrita é notório o descaso com o Turismo de Juiz de Fora por parte do poder público municipal.

A pesquisa revelou também que atualmente não existe nenhum projeto direcionado para o turismo, e o que existia foi extinto na tentativa de sanar as dividas oriundas da administração anterior. Pois seus custos eram arcados pela prefeitura.

O projeto citado no parágrafo acima era referente ao turismo de Juiz de Fora que esteve em andamento até ano passado, sua idéia inicial era levar os turistas para conhecer Juiz de Fora, o projeto deixou de ser voltado apenas para atender a turistas e passou também a dar importância ao público local quando notou-se a existência de interesse dos juizforanos pelo passeio e pelo o conhecimento.

O projeto possuiu quatro roteiros distintos mas apenas três deles interessam para a pesquisa, são eles:Roteiro cultural( Parque Mariano Procópio, Usina de Marmelos,Parque da Lajinha, Morro do Imperador ( Morro do Cristo), ROTEIRO ETNIAS RELIGIOSAS (Igreja Metodista Central, Igreja Greco-Melquita São Jorge, Igreja da Glória, Catedral Metropolitana - Santo Antônio), Roteiro Museus e cultura( Museu Ferroviário, Museu de Crédito Real, Fórum da Cultura). 


\subsection{A participação da comunidade de Juiz de Fora na preservação do patrimônio cultural}

Neves(2004) apresenta a aprovação de uma lei cujo segundo artigo será descrito abaixo:

Art.2ำ A proteção do Patrimônio Cultural será feita em conformidade com a natureza do bem, observado o Decreto- Lei no 25, de 30 de novembro de 1937 e o Decreto no 3551 , de 04 de agosto de 2000 e poderá compreender :

I - tombamento do bem e delimitação de seu entorno, quando for o caso

II -registro de bem imaterial;

III - declaração de interesse cultural do bem.

O Município estimulará a participação da comunidade na preservação do Patrimônio Cultural.

Além desta lei existe em Juiz de Fora a FUNALFA que foi fundada em 14 de setembro de 1978, a Fundação Cultural Alfredo Ferreira Lage - FUNALFA, primeira fundação municipal no setor cultural criada em Minas Gerais. Busca a inovação, a integração, o resgate do patrimônio artístico e a revitalização do pioneirismo de Juiz de Fora como dinâmico núcleo de cultura. Ao investir na realização de atividades múltiplas e ao assegurar o compromisso com a arte na perspectiva de um desafio democrático, a FUNALFA promove a valorização do setor cultural na cidade.

Atualmente a FUNALFA possui sede no prédio histórico do paço municipal, na esquina da avenida Rio Branco com a rua Halfeld. Recentemente trabalhou para realizar o resgate de bens importantes para Juiz de Fora, são eles: Museu Mariano Procópio, Cine -Theatro Central, o Centro Cultural Bernardo Mascarenhas e a Biblioteca Municipal Murilo Mendes. A FUNALFA tem também entre seus objetivos incentivar campanhas de estímulo à solidariedade e à cidadania, implementadas numa perspectiva de inclusão social. 


\subsubsection{Entrevistas com profissionais do turismo e cultura de Juiz de Fora}

\subsubsection{Entrevista com diretor de divisão do Patrimônio Cultural da FUNALFA}

O Diretor de Divisão de Patrimônio cultural Paulo Gawryszewski, durante a entrevista acrescentou à pesquisa sua opinião a respeito do potencial turístico histórico cultural da Manchester mineira.

1) O senhor acredita que exista um potencial turístico Histórico Cultural em Juiz de Fora?

Existe um potencial grande, mas embora faça-se um esforço para que a população se conscientize está sendo uma tarefa difícil. Um exemplo de atrativo histórico cultural é O painel de Candido Portinari "As quatro estações", é um dos doze existentes no mundo, e Juiz de Fora foi premiada internacionalmente por isso. A cidade possui também quinze museus com acervos diversos e poucas pessoas sabem da existência. As pessoas não sabem que podem levar crianças para visitar estes museus.

2) Se sim, você considera que o potencial turístico é utilizado?

Não da maneira como deveria, as pessoas nos fins de semana e feriados sempre viajam dizem que em Juiz de Fora não tem nada para fazer. Mas possui muita coisa para fazer.

3) O senhor acha que a população Juizforana valoriza seu patrimônio cultural?

A gente tem trabalhado para que a população conheça valorize e proteja 0 patrimônio, no entanto a tarefa está fugindo ao controle. Algumas pessoas fazem mau uso do nosso patrimônio. Tanto o público quanto o privado.

4)A FUNALFA possui algum projeto que tenha como objetivo a valorização histórico cultural e o desenvolvimento comunitária, em Juiz de Fora?

Paulo afirma que existe um programa anual, que acontece no mês de maio, $A$ FUNALFA monta sete circuitos com três museus cada um, e as escolas se inscrevem 
para levar seus alunos para visitarem estes museus que fazem parte de uma rede que se chamada Educação Patrimonial. Esta é uma reunião voluntária das instituições. O objetivo é levar os alunos para conhecerem os acervos, o projeto acontece a quatro anos. E procura divulgar os museus que Juiz de Fora possui alem do Museu Mariano Procópio.

\subsubsection{Entrevista com coordenadora do Curso de Turismo da Universidade Federal de Juiz de Fora}

Outro fator que poderia auxiliar muito para o desenvolvimento do Turismo histórico cultural em Juiz de Fora é a presença de muitas faculdades de Turismo, a presença desta Instituições deveria incentivar a criação de projetos comunitários que causassem interação entre comunidades e pessoas que nela vivem, buscando valorizar o potencial existente e trabalhar em parceria com a administração municipal. Sendo a mais representativa devido ao maior número de alunos, e também por ser uma Instituição Federal, a pesquisadora entrevisto a Coordenadora do Curso de Turismo da Universidade Federal de Juiz de Fora, a professora Alice Arcuri sobre a questão do turismo histórico cultural em Juiz de Fora.

1) A Senhora acredita que exista um potencial Turístico Histórico Cultural em Juiz de Fora?

A professora respondeu : "Sim, eu acredito que exista um potencial Turístico Histórico Cultural em Juiz de Fora, mas não acho que este potencial seja comparado ao potencial de cidades como Ouro Preto, Mariana, Diamantina"

"Acho que o fato de atualmente Juiz de Fora ser um grande centro urbano não o potencial histórico -cultural nela existente torna-se ofuscado."

2) Se sim, você considera que o potencial turístico existente é utilizado?

"Não acredito que seja utilizado bem não, muito mal."

"No Brasil o turismo predominante é o de Sol e Praia, os brasileiros não tem uma cultura, principalmente trabalhada desde a infância, voltada para o turismo histórico cultural. Você não consegue formar público para museus por exemplo" , e Juiz de Fora está inserida neste contexto de descaso com a história para a própria população." 
"Alice Arcuri destaca também que o turismo deveria estar presente na educação de ensino fundamental, com objetivo de estimular o interesse por questões culturais, étnicas, e conhecimento de lugares."

Outra questão bastante destacada por Alice é que é preciso que haver um incentivo público, ela pensa que tudo parte das políticas públicas e exemplifica a falta de interesse público com a extinção da Secretaria de Turismo, comércio e indústria, "Foi um passo para trás."

3)A Universidade Federal de Juiz de Fora possui algum projeto que tenha como objetivo a valorização histórico cultural e o desenvolvimento comunitário, em Juiz de Fora?

A professora responde que o curso de Turismo da Universidade Federal de Juiz de Fora ainda não possui projeto voltado para a valorização histórico cultural, mas que haverá uma reforma na grade curricular do curso, em que o aluno fará dois anos e meio de disciplinas voltadas para ciências humanas, e posteriormente ele fará a escolha de estudar o turismo relacionado à cultura ou o turismo relacionado a áreas naturais. A partir desta reforma a professora acredita que passaram a surgir projetos que trabalhem para a valorização da cultura buscando o desenvolvimento comunitário.

\subsubsection{Entrevista com o diretor superintendente do Museu Mariano Procópio}

1) O Senhor acredita que exista um potencial Turístico Histórico Cultural em Juiz de Fora?

Douglas afirma acreditar sim na existência de um potencial Turístico Histórico Cultural em Juiz de Fora inclusive por estar envolvido em pesquisas relacionadas à história da cidade que segundo ele possui grande importância histórica e ser pioneira em várias ações no século XIX.

"Nós temos a primeira usina hidrelétrica da América, e o primeiro grande Museu de Minas Gerais, então acho que Juiz de Fora tem potencial sim, que talvez não seja divulgado o bastante. Temos também inúmeras outras opções para explorarmos este potencial turístico histórico da cidade."

O diretor do Museu Mariano Procópio afirma também que por ser uma cidade pólo, Juiz de Fora deveria ter um roteiro conjunto com as cidades do entorno. Com uma estruturação sólida, e que valorizasse a história da cidade. $E$ ainda questiona 
qual está sendo os destino das históricas fazendas de café da nossa região, e exemplifica a Fazenda São Mateus por onde passaram alguns inconfidentes, entre eles o Tiradentes.

2) Se sim, você considera que o potencial turístico existente é utilizado?

"Não, existem algumas ações que precisam ser feitas aliando educação"

Fazolato apesar de acreditar que existe um potencial turístico histórico cultural responde que este não é bem aproveitado e que são necessárias algumas ações aliando educação com cultura, e que de certa forma precisa trabalhar com as crianças na parte de educação, ele julga necessário uma diretriz conjunta para explorar a turismo histórico de maneira que se crie esta idéia de valorização do patrimônio e da cultura. Trabalhar com crianças e com adultos, $\mathrm{Na}$ rede hoteleira por exemplo os funcionários não sabem sugerir a um hóspede uma opção de lazer que não sejam os bares de Juiz de Fora.

Apesar de estarmos no roteiro da estrada real, de termos potencialidade, precisamos de um trabalho conjunto mais intenso para se desenvolver isso. Alem do Museu Mariano Procópio temos o museu Murilo Mendes que tem um acervo maravilhoso, com Chagal, Picasso, temos Cine theatro central, Mascarenhas, a primeira usina hidrelétrica. Podemos realizar um roteiro no centro da cidade com essas construções do sec XIX e inicio do sec XX que criaram um diferencial de cidade com um shopping a céu aberto. Acho que isso precisa ser tratado de uma forma conjunta para que possamos aproveitar adequadamente.

3)O senhor acha que a população Juizforana valoriza seu patrimônio cultural?

"A população não valoriza devidamente, porque também não tem noção da importância que a cidade tem e o que ela pode a oferecer. É preciso conscientizar, educar, capacitar mão de obra para a partir daí explorar e as pessoas terem noção de que possuem um patrimônio com que a cidade é privilegiada."

"A cidade já possui uma política de preservação de patrimônio, de tombamentos. Temos o diferencial por Em 1889 termos sido uma cidade muito rica, a que mais recolheu impostos em Minas Gerais. Elite financeira e cultural proporcionou o legado patrimônio. Permitindo a aquisição de um patrimônio diferenciado um exemplo disto é o cine-theatro central." 
4) O Museu Mariano Procópio possui algum projeto que tenha como objetivo a valorização histórico cultural e o desenvolvimento comunitário, em Juiz de Fora.

"Museu está passando por uma série de obras que deverão ser retomadas e todas tem no planejamento aumentar o número de visitantes, atraí-los com projetos interessantes. Possuímos um projeto mensal "o clube ecológico”, tem visitas guiadas, recebemos escola públicas e particulares, entidades,instituições. O museu possui um cadastro das escolas, e procuramos entrar em contato regularmente para que a visita ao Mariano Procópio seja colocado em seus calendários."

O projeto existente "clube ecológico" não é seqüencial. Ele é aberto ao público e acontece uma vez por mês.

Analisando as entrevistas a autora obteve as percepções e opiniões comuns entre os entrevistados. Todos concordaram que existe um potencial turístico histórico cultural em Juiz de Fora e compartilham também da opinião de que o patrimônio não é bem utilizado para o desenvolvimento do turismo.

Outra opinião comum dos entrevistados é a de que a população Juizforana não valoriza o patrimônio histórico cultural da cidade, a falta de conhecimento da população a respeito do patrimônio histórico cultural de Juiz de Fora é apontado como o principal fator para a desvalorização do mesmo. Além disto não existe na cidade projeto que tenha como objetivo a valorização cultural e o desenvolvimento comunitário. A ausência de projetos desta natureza impossibilita o desenvolvimento da atividade turística de maneira satisfatória.

\subsection{Análise integrada dos dados}

Após a realização das pesquisas e das entrevistas foi possível confirmar a real existência de um potencial turístico histórico cultural em Juiz de Fora.

A busca por atrativos turísticos históricos acompanhados de suas informações relevantes no decorrer do desenvolvimento da cidade possibilitou a confirmação da importante presença de Juiz de Fora na história de Minas Gerais e do Brasil foi confirmada. 
Pesquisas relacionadas ao potencial turístico e a existência de infra-estrutura básica e de apoio ao turista também foram satisfatórias para o desenvolvimento da atividade na cidade, porém apontaram falta de treinamento e capacitação da mão de obra.

No que tange ao aproveitamento do potencial turístico histórico cultural, as opiniões dos entrevistados juntamente com o resultado da pesquisa realizada em 2004 para a elaboração do Plano Estratégico Setorial de Turismo que o potencial não é utilizado. Um fator grave relacionado a este fato é a falta de conhecimento dos juizforanos a respeito da relevância histórico cultural da cidade e a falta de cuidado com o Patrimônio Cultural existente.Fatores estes que contribuem para a perda de identidade do local. Foi possível notar a não existência de projetos que envolvam as comunidades com seu patrimônio cultural. Além disto, a falta de interesse do poder público em incentivar projetos relacionados ao turismo e desenvolvimento cultural.

Durante as pesquisas e entrevistas diversas vezes apareceu a política de tombamentos utilizada pela Prefeitura Municipal de Juiz de Fora como atitude protecionista, porém apenas o tombamento de algum bem ou manifestação cultural não garante que este estará cuidado com objetivo de preservar a memória e a identidade do local.

Os representantes da administração do Museu Mariano Procópio, o Museu Ferroviário, e a FUNALFA afirmaram que as instituições por eles representadas possuem projetos que tenha como objetivo a valorização histórico cultural e o desenvolvimento comunitário. Mas em ambos os casos, os projetos descritos apresentaram como características: a realização de atividades com um número muito grande de espectadores de uma só vez, fator este que minimiza os efeitos didáticos da proposta alem de não serem atividades que mantêm continuidade do publico alvo.

Os projetos de educação ambiental e patrimonial devem ser realizados constantemente e com grupos fixos e com número limitados de pessoas para que alcancem seus objetivos satisfatoriamente.

No Museu Ferroviário os projetos existentes envolvem a comunidade, mas em sua maioria são projetos de caráter social, que conseguem levar crianças, adolescentes e adultos para junto do patrimônio ali existente. Além de um projeto de visitação também com escolas e grupos variados de pessoas. Mas a atitude demonstra não estar causando interesse da comunidade. 
Os entrevistados confirmaram a existência de uma política de tombamento no município, porém ela não é suficiente para a preservação do patrimônio cultural, e também não é eficiente no estimulo ao desenvolvimento do Turismo Histórico Cultural.

Os entrevistados concordaram que para que ocorra um desenvolvimento do turismo histórico cultural em Juiz de Fora seria importante que houvesse investimento do poder público municipal.

Outro fato revelado durante a realização da pesquisa e das entrevistas é a ausência de continuidade com projetos relacionados a turismo nas trocas de governo. 


\section{CONSIDERAÇÕES FINAIS}

O exposto estudo está relacionado, ao longo de seu progresso, nas possibilidades do desenvolvimento do turismo histórico cultural em Juiz de Fora e o seu principal objetivo foi investigar o potencial do Turismo Histórico Cultural de Juiz de Fora. Para realizar o estudo foram feitas pesquisas com objetivo de levantar os atrativos históricos culturais que favoreçam o turismo da cidade e demonstrar a importância histórica destes para Juiz de Fora, foram investigadas as condições em que se encontram os atrativos histórico culturais existentes, e também foi feita uma busca de informações sobre as condições de infra-estrutura básica e da infraestrutura de apoio ao turista no local estudado

A partir da contextualização histórica do surgimento da cidade realizada durante a pesquisa documental foi possível confirmar o surgimento de Juiz de Fora durante um importante período da História do Brasil - a mineração. A investigação possibilitou a confirmação da existência do potencial turístico e também a suspeita de que o turismo histórico cultural não acontece em Juiz de Fora devido à falta de interesse, incentivo e planejamento originado do poder público com relação ao desenvolvimento da atividade. Apesar de possuir bons hotéis, bares, restaurantes, a infra estrutura de apoio ao turista não é satisfatória pois prefeitura não tem interesse em investir no turismo local.

Uma das suposições feitas pelos formadores de opinião para a falta de interesse do governo é que o Brasil no ponto de vista Histórico cultural as pessoas não são educadas a visitarem museus, lugares históricos, eventos que valorizam cultura local, entre outros. Ao tratarmos a lugares histórico-culturais como atrativo turístico é possível a percepção de hábitos que desvalorizam a importância desse tipo de turismo e supervaloriza o turismo popularizado no Brasil - turismo de sol e mar.

Em Juiz de Fora, apesar de possuir vários lugares para lazer e cultura, foi possível perceber que seus moradores preferem se afastar nos feriados e fins de semana a ficar na cidade e visitar os espaços existentes. Muitos alegam não ter nada para fazer na cidade. Desta forma é possível notar que existe uma desvalorização do lugar pela própria população, fator este negativo para o desenvolvimento do turismo e para a economia do local. Os juizforanos saem da cidade e levam consigo dinheiro para gastar fora dela, e a chegada de turistas por sua vez não é suficiente para suprir 
esta saída. O turismo sustentável não deve basear-se apenas em objetivos econômicos, no entanto a atividade pode se desenvolver sustentavelmente e beneficiar a economia do local.

Apesar do governo municipal possuir algumas medidas de proteção com o patrimônio através de tombamentos e fazer alguns investimentos em restauração, entre os projetos apresentados à comunidade não existem projetos de resgate e valorização cultural local, em sua maioria são projetos de caráter assistencialista ou de produção cultural. Este último muitas vezes pode se confundir com projetos citados acima. O resultado é a falta de conhecimento a respeito do rico legado cultural que existe na cidade.

A presença da Universidade Federal De Juiz de Fora, pode ser interessante para a formação de parcerias com a Prefeitura Municipal de Juiz de Fora, pois poderia reduzir os custos de projetos culturais utilizando mão de obra universitária. Os universitários por sua vez se beneficiariam com a oportunidade de ter contato maior com a profissionalização, e de adquirir maior experiência.

Outras atitudes precisam ser tomadas para inserir o interesse pelo patrimônio cultural, pois a partir da valorização do Patrimônio cultural pela própria comunidade, assim o desenvolvimento do turismo acontecerá com maior naturalidade.

A educação patrimonial com profissionais dos serviços turísticos, serviços de apoio ao turista(hotéis, bares, restaurantes, até mesmo comércio local) e também do comércio local para que conheçam melhor o legado cultural da cidade e saibam dar informações aos turistas à respeito do patrimônio local, de localização, opções de lazer e de passeio na cidade. Além da capacitação dos profissionais para melhor atender os clientes. Esta ação deve ser feita em parceria entre poder público e privado, visto que é vantajosa para ambas, pois teria como objetivo estender a estadia de um turista que já se encontra na cidade.

Outra atitude importante que precisa ser tomada para que o processo evolua melhor é a atualização do inventário e das pesquisas relacionadas ao turismo em Juiz de Fora.

O trabalho apresentado talvez estimule a elaboração de futuros projetos que tenham como um de seus objetivos a educação patrimonial na cidade de Juiz de Fora. Desta forma além de auxiliar no aprendizado, a atitude pode ser determinante para incentivar uma participação maior da comunidade na preservação do seu patrimônio, 
e outros estudos que contribuam para a elaboração de projetos com participação comunitária que tenha como objetivo a valorização do lugar em que vivem, pois este pode ser o caminho do sucesso em se tratando de turismo histórico cultural de caráter sustentável. 


\section{REFERÊNCIAS:}

AMARAL, Aelson Faria. Juiz de Fora ontem e hoje.Juiz de Fora:FUNALFA,2006.

BRASIL, Ministério da Cultura. Turismo cultural,2006.

BARRETO, M;BURGOS, R;FRENKEL,D; Turismo políticas públicas e relações internacionais: São Paulo: Papirus,2003.

CLEMENTE, Vicente de Paulo. Os alemães e a Borboleta,Cultura Alemã:2007.

DIAS, Renato Henrique. Juiz de Fora em dois Tempos. Juiz de Fora: Esdeva,2000.

ESTEVES, Albino.Álbum de Juiz de Fora. Juiz de Fora:1915.

FAZOLATO, Douglas.Juiz de Fora, Primeiros tempos in BASTOS,Wilson. Caminho novo, espinha dorsal de Minas.Juiz de Fora:FUNALFA,2004.

GODOY, A. Introdução à Pesquisa Qualitativa e suas Possibilidades. Revista de

Administração de Empresas. São Paulo, v. 35, n. 2, Março- Abril, 1995, p. 57-63.

GOMES, Lindolfo. A tradicional fazenda de São Mateus, em Juiz de Fora: Dias Cardoso, 1933

IGNARRA, Luiz Renato. Fundamentos do Turismo. São Paulo:pioneira,2001

JUIZ DE FORA. Prefeitura Municipal.Plano estratégico setorial de Turismo de Juiz de Fora,2004.

KRIPPENDORF, Jost , Sociologia do Turismo.São Paulo: Aleph.2003

MOESCH, Marutschka. A produção do saber turístico.São Paulo:Contexto;2000

MONTORO, Tânia. Cultura do Turismo, desafios e praticas socioambientais.Brasília: Thesaurus,2003.

NEVES; José. DELGADO; Inácio. OLIVEIRA;Mônica. Juiz de Fora, história, texto e imagem. Juiz de Fora:FUNALFA:2004.

NEVES, José Luís. Pesquisa Qualitativa - características, usos e possibilidades. Caderno de pesquisas em administração, São Paulo, №3, 2ำ Sem 1996.Disponível em HTTP://www.ead.fea.usp.br/cad-pesqlarquivos/C03- art06.pdf em 29/03/2009 16:50

NEVES;José Alberto.Memória Urbe,Bens tombados.Juiz de Fora:FUNALFA;2004.

NEVES;Marcos.Rua Halfeld. Juiz de Fora:Tribuna de Minas;1998.

OLIVEIRA,Mônica Ribeiro.Negócios de famílias: mercado terra e poder na formação da cafeicultura mineira, 1780 a 1870. Niterói:UFF,1999(Dissertação de Doutorado apresentada à Universidade Federal Fluminense

PEREIRA,Mabel;SILVA,Raquel;SANTIAGO,Wessila;Cristo redentor do Brasil, tradição e reinvenção católica.Juiz de Fora: FUNALFA,2006

RODRIGUES in PINSK; Jaime; FUNARI; Pedro Paulo, Turismo e Patrimônio Cultural.São Paulo:contexto; 2007

PORTUGUEZ,Anderson: Consumo e espaço,Turismo,Lazer e outros temas. São Paulo:Roca;2001 
SWARBROOKE;John.Turismo Sustentável, gestão e marketing. 2a edição. São Paulo:Aleph,2002.

SWARBROOKE, John; HORNER,Susan. O comportamento do consumidor no Turismo. São Paulo: Aleph,2002.

YÁZIGl; Eduardo. A alma do lugar. Turismo, planejamento e cotidiano. São Paulo:contexto,2002. 